\title{
Research on Mushroom as a Potential Source of Nutraceuticals: A Review on Indian Perspective
}

\author{
Selima Khatun ${ }^{1}$, Aminul Islam $^{2}$, Ugur Cakilcioglu $^{3^{*}}$ \\ and Narayan C. Chatterjee ${ }^{1}$ \\ ${ }^{1}$ Mycology and Plant Pathology Laboratory, Centre of Advanced Study, \\ Department of Botany, University of Burdwan, Burdwan 713104, West Bengal, India \\ ${ }^{2}$ Natreon Inc., Salt Lake City, Kolkata 700091, India. \\ ${ }^{3}$ Elazig Directorate of National Education, Elazig 23100, Turkey.
}

Review Article

Received $8^{\text {th }}$ July 2011

Accepted $8^{\text {th }}$ December 2011

Online Ready $11^{\text {th }}$ December 2011

\section{ABSTRACT}

Mushrooms are highly nutritive, low-calorie food with good quality proteins, vitamins and minerals. Mushrooms are an important natural source of foods and medicines. Traditional aboriginals knew the medicinal importance of edible and wild mushrooms and these are now being screened for their bioactivity in various ailments. Mushroom represents a major and untapped source of potent new pharmaceutical products. A wide range of activities including antitumour, cardiovascular and antimicrobial are reported in mushrooms. In developing countries like India mushroom progress is a boon in the field of food, medicine, and in generating employment. The alternative systems of medicine utilize the curative properties of mushrooms. By virtue of having high fibre, low fat and low starch, edible mushrooms have been considered to be ideal food for obese persons and for diabetics to prevent hyperglycaemia. They are also known to possess promising antioxidative, cardiovascular, hypercholesterolemia, antimicrobial, hepato-protective and anticancer effects. The present review aimed to discuss on mushroom cultivation as well as medicinal importance as nutraceuticals, antioxidatives, cardiovascular, hypercholesterolemia, antimicrobial, hepatoprotective, anticancer, clinical trials and availability of mushroom medicines from Indian context.

Keywords: Mushroom; cultivation; antioxidative; cardiovascular; Hypercholesterolemia; antimicrobial; antitumor; clinical trial; Indian context. 


\section{INTRODUCTION}

A nutraceuticals can be defined as a substance that may be considered a food or part of a food that provides medical or health benefits like the prevention and treatment of disease. Mushrooms have become attractive as a functional food and as a source for the development of drugs and nutraceuticals (Lakhanpal and Rana, 2005) responsible with their antioxidant, antitumor (Jones and Janardhanan, 2000) and antimicrobial properties. Besides their pharmacological features, mushrooms are becoming more important in our diet due to their nutritional value, related to high protein and low fat / energy contents (Agahar-Murugkar and Subbulakshmi, 2005). Trametes versicolor (L.) Lioyd has been considered among the 25 major medicinal macrofungi worldwide (Boa, 2004), mainly due to its traditional usage. Interesting polysaccharopeptides have been purified from this species, showing experimental immunomodulatory and anti-cancer effects (Cheng and Leung, 2008; Ramberg et al., 2010). A native strain of Trametes versicolor (Coriolaceae) was isolated and cultivated under laboratory conditions. Higher mushroom yield of $173.8 \mathrm{~g}$ was recorded on supplemented oak sawdust, reaching a biological efficiency of $20.3 \%$ (Guerrero et al., 2011). In India, numbers of species of mushroom have been listed by various workers (Manjula, 1983; Bhawani and Nair, 1987; Saini and Atri, 1993; Verma et al., 1995; Natrajan,1995; Atri et al., 1995; Lakhanpal, 1995; Doshi and Sharma, 1997; Tiwari et al., 2009). Uttarkhand a hill state of India is gifted with a rich medicinal flora that includes Ganoderma, Cordyceps (Singh et al., 2007; Singh et al., 2008; Singh et al., 2009) and Auricularia (Singh et al, 2007). Codycepin and cordycepic acid are regarded as the most important constituents of Cordyceps sinensis and owe high medicinal significance (Chatterjee et al., 1957). In developing countries like India mushrooms are boon for progress in the fields of food, medicine and unemployment. Mushrooms in the twentieth century are well known to people all over the Asian countries as an important bio-source of novel secondary metabolites. In India, particularly the alternative systems of medicine, utilize the curative properties of mushrooms. The secondary metabolites of these mushrooms are chemically diverse and possess a wide spectrum of biological activities, which are explored in traditional medicines and in new targets of molecular biology. They have important present status and possess a potential to design future strategies for human health values. Hence, this review paper deals with the Indian mushrooms cultivation as well as potential sources of protein and nutraceuticals.

\subsection{Mushroom Cultivation in India}

Pleurotus ostreatus mushroom cultivation is very popular and next to Agaricus bisporus mushroom in India in popularity and consumption. This together form bulk of edible mushrooms produced in country (about 100000 tons per annum, 2008-09) [Dhar and Sharma, 2009]. In India Pleurotus sajor-caju has been successfully cultivated on banana pseudo-stem and paddy straw (Jandiak, 1974; Jandiak and Kapoor, 1974). Rice straw, wheat straw, ragi straw, hulled maize cab, waste paper were tried in different studies (Jandiak, 1974; Sivaprakasam et al., 1979; Thilagavathi et al., 1991). Sincere efforts to bring mushrooms under cultivation were made after the commissioning of a scheme "Development of mushroom cultivation in Himachal Pradesh", at Solan by the ICAR's Directorate of Mushroom Research in 1961, has been reported to be under cultivation in India (Jandiak, 1997). Use of costly substrate for growing oyster mushroom increases their cost of production. So there was need to search for certain alternative materials which should be available in sufficient quantity at relatively cheaper price (Arya and Arya, 2003). Pleurotus has been reported to grow readily on a number of non-conventional substrates (Das et al., 2000; Mukherjee and Nandi, 2002; Nageswaran et al., 2003). In West Bengal, 
India water hyacinth (Eicchornia crassipes Solms.), a low-cost supplement for oyster mushroom (Pleurotus florida) cultivation (Bandopadhyay and Chatterjee, 2009). It is reported that highest yield $(923.7 \mathrm{~g})$ of $P$. florida with biological efficiency (BE) of $184.7 \%$ was obtained after three flushes in beds of combined (paddy straw and water hyacinth) substrates followed by paddy straw alone $(698.1 \mathrm{~g}$ and $139.6 \% \mathrm{BE})$ and water hyacinth alone (614.1g and 122.8\% BE) [Bandopadhyay and Chatterjee, 2009]. West Bengal is one of the leading agriculturally and industrially advanced state in India of which Burdwan district is worth mentioned. The Burdwan district of West Bengal, India is popularly known as a 'Granary of rice district', where it's agricultural left-overs are abundantly available. All these unutilized wastes together with other garbage materials which pollute the environment may well be utilized for cultivation of protein-rich mushrooms (Medda, 2001). With the help of biotechnological process, the huge organic wastes can be re-cycled through mushroom cultivation for the production of food, fuel and fertilizers (Madan, 1994). Spent residues after the cultivation of edible mushroom could be better source of biologically pre-treated substrates for biogas production (Madan, 1994). Recycling of agro wastes is done through mushroom cultivation (Madan, 1994). In Chhattisgarh, the village people practiced mushroom cultivation by their own ways using paddy straw as a substrate and bring it to local market where it fetches for good prices (Thakur et al., 2003), and the hunting of mushrooms is an occupation of tribal particularly in rainy season (Tiwari et al., 2009). It is reported that the nutraceuticals properties of the fruiting of $G$. lucidum harvested from the organic cultivation were analysed (Perumal, 2009).

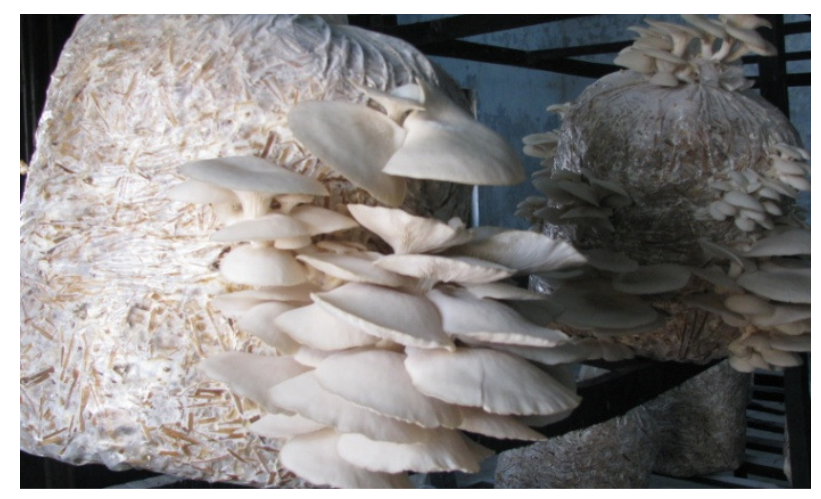

Figure 1. Pleurotus florida (Mont.) Singer

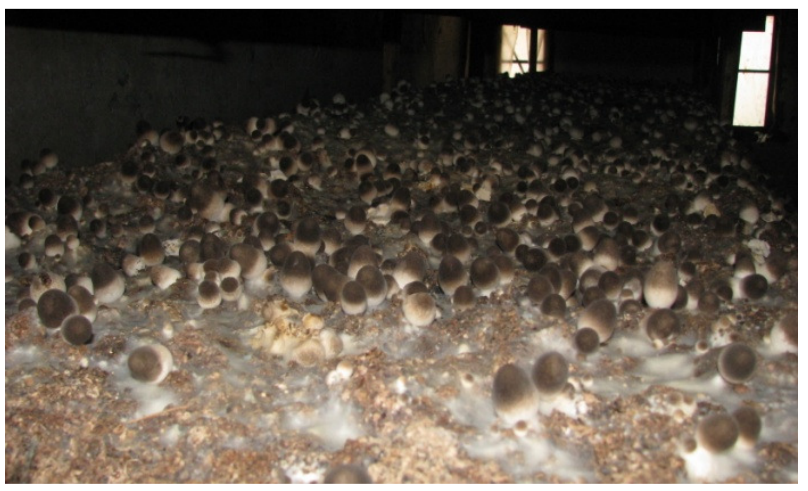

Figure 2. Volvariella volvacea (Bull. ex Fr.) Sing. 


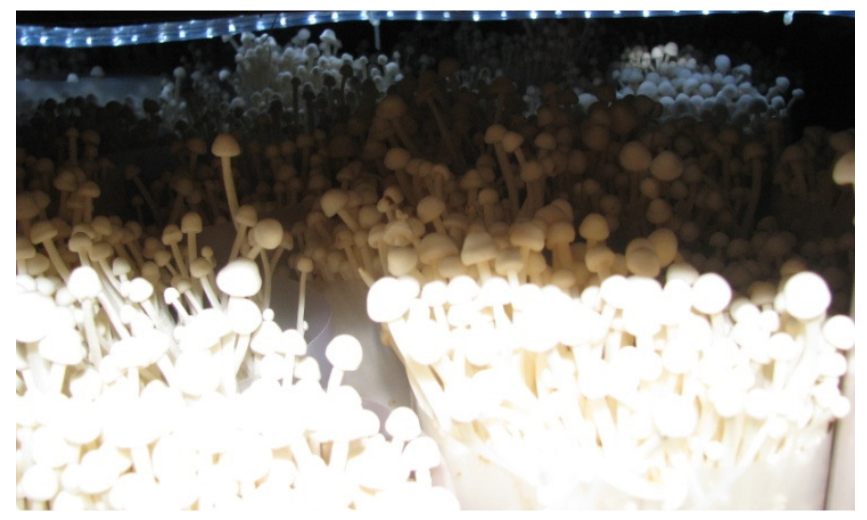

Figure 3. Flamulina velutipes (Curtis) Karst.

\subsection{Nutraceutical and Antioxidative Properties of Mushroom}

It is probable that from its earliest beginning man has utilized mushrooms as a food (Rahi et al., 2004). Mushroom is an excellent source of folic acid, the blood building vitamin that prevents anaemia (Kannaiyan and Ramaswamy, 1980; Bisaria et al., 1987). Mushroom protein is comparable to muscle protein in terms of nutritive value (Kannaiyan and Ramaswamy, 1980). The species that have been properly analysed for medicinal value are: Ganoderma lucidum (Reishi), Lentinus edodes (Shiitake), Grifola frondosa (Maitake), Agaricus blazei (Hime-matsutake), Cordyceps militaris (Caterpillar fungus), Pleurotus ostreatus (Oyster mushroom) and Hericium erinaceous (Lions mane). There are many more species of cultivated and wild edible and non-edible mushrooms that have been analysed for both their nutritional and nutraceuticals components (Lakhanpal and Rana, 2005). The active constituents found in mushrooms are polysaccharides, dietary fibres, oligosaccharides, triterpenoids, peptides and proteins, alcohols and phenols, and mineral elements (Pardeshi and Pardeshi, 2009) such as zinc, copper, iodine, selenium and iron, vitamins, amino acids etc. These have been found to boost the immune system, have anti-cancerous properties, act as anti-hypercholesterolemia and hepato-protective agents, show anti-HIV activity and anti-viral activity, and ameliorate the toxic effect of chemo- and radiotherapy. Many of the species are known to be aphrodisiacs. Oxidation is essential for all living organisms for the production of energy to fuel biological processes. However, oxygen-centred free radicals and other reactive oxygen species that are continuously produced in vivo, result in cell death and tissue damage. Oxidative damage caused by these free radicals may be related to ageing and diseases, such as atherosclerosis, diabetes, cancer and cirrhosis. The antioxidant potential has been studied from water and methanol extracts of fruiting bodies of 23 species of mushrooms naturally grown in different geographic locations of India (Nethravathi et al., 2006). Three species of Pleurotus florida, P. pulmonarius and P. citrinopileatus can be cultivated almost throughout the year in the plains of India were examined for their antioxidant potentialities with a view to popularize medicinal mushrooms among common middle class people at low-cost instead of administering costly medicines. Reducing power, chelating activity of $\mathrm{Fe}^{2+}$ and total phenol were observed to be higher in $P$. florida than in $P$. pulmonarius and $P$. citrinopileatus respectively. Among antioxidative enzymes, $P$. florida (Figure 1) exhibited highest peroxidase and superoxide dismutase (SOD) where as catalase activity was found to be highest in P. pulmonarius (Khatun et al., 2009). The alcohol and aqueous extracts of $G$. lucidum and $C$. sinensis showed a high anti-oxidative activity by giving protection against oxidative DNA damage (Jones and Janardhanan, 2000). It is 
reported that the reducing power and chelating activity of $\mathrm{Fe}^{2+}$ of $\mathrm{G}$. lucidum and C. sinensis ethanol extract increased with increase in concentration. The G. lucidum ethanol extract showed higher anti-oxidative properties than $C$. sinensis, probably due to differences in the compounds present in the fruiting bodies (Singh et al., 2007). Previous workers obtained

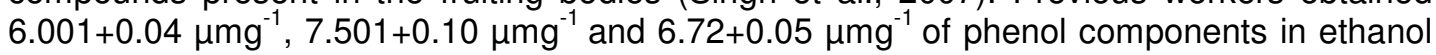
extract of $P$. sajor-caju, P. florida and $P$. aureovillosus respectively (Laganathan et al., 2008; Laganathan et al., 2009; Laganathan et al., 2010). It is showed that antioxidant activity of Phellinus rimosus seems to be more effective than the Pleurotus florida, $P$. sajour-caju and G. Iucidum (Lakshmi et al., 2004; Ajith and Janardhanan, 2003). It is obtained that the mushroom may be a potential source of therapeutically useful antioxidant (Jayakumar et al., 2006; Sudha et al., 2008; Nitha et al., 2010). Phenols contained good antioxidant properties (Sasidharan et al., 2007; Khatun et al., 2009), antimutagenic properties (Lakshmi et al., 2003) and anticancer properties (Ahmad and Mukhtar, 1999). Fruiting bodies of medicinal mushroom (G. lucidum) contains polysaccharides, triterpenoids, adenosine, germanium, protein (L2-8), amino acids etc. found to have antitumor and immuno-modulating affect (Singh et al., 2007; Singh et al., 2008; Singh et al., 2009).

The dominant and most frequently found species are Phellinus senex, $P$. rimosus, $P$. badius, P. fastuosus, P. adamantinus, P. caryophylli and P. durrissimus (Sharma, 1995). About 18 species are found to occur in Kerala, most of them are wood inhabiting (Leelavathy and Ganesh, 2000). P. rimosus (Berk) Pilat is found growing on jackfruit tree trunks in Kerala. In Kerala, this mushroom is commonly found on living Moraceae members. In Chinese medicine hot water extract of the fruiting bodies of Phellinus species have been used for an extensive range of ailments and it is believed to work as a miracle drug refreshing the human body and prolong longevity (Ying et al., 1987). Recent studies have compared hot water extract of Phellinus with other anticancer mushrooms. The Phellinus extract showed the strongest evidence of tumor proliferation suppression (Mizuno, 2000). Methanol extract of $P$. rimosus effectively reduced ferric ion in FRAP assay and scavenged DPPH radicals (Ajith and Janardhanan, 2007).

Extracts from fruiting bodies and mycelia of G. lucidum occurring in South India were found to possess in vitro antioxidant activity (Jones and Janardhanan, 2000; Lakshmi et al., 2003) and antimutagenic activities (Lakshmi et al., 2003).

The results of the antioxidant assays (Ajith and Janardhanan, 2007) showed that ethyl acetate, methanol and aqueous extract of $\mathrm{G}$. lucidum effectively scavenged the $\mathrm{O} 2$ and $\mathrm{OH}$ radicals (Table 1). However the aqueous extract was not effective to inhibit the ferrous ion induced lipid peroxidation (Jones and Janardhanan, 2000). The extract showed significant reducing power and radical scavenging property as evident from FRAP assay (Ajith and Janardhanan, 2007) and DPPH radical scavenging assay (Lakshmi et al., 2004; Ajith and Janardhanan, 2007).

Pleurotus species have high medicinal value. Compounds extracted from these mushrooms exhibit activity against various chronic diseases including hypertension, hypercholesterolemia (Gunde-Cimmerman et al., 1993; Gunde-Cimmerman et al., 1999; Wasser, 2002). The medicinal beneficial effects of Pleurotus species were discovered independently in different countries. The awareness of their medicinal properties came not only from Asia but from the folklore of central Europe, South America and Africa (GundeCimmerman et al., 1999). Oyster mushrooms (Pleurotus species) are excellently edible and nutritious, rank among one of the most widely cultivated mushrooms in the world (Chang, 1999). Species of Pleurotus are found to possess significant antioxidant, anti-inflammatory 
and antitumor activities (Jose and Janardhanan, 2000; Jose et al., 2002). The methanol extract of fruiting bodies of Pleurotus florida was found to possess $\mathrm{OH}$ radical scavenging and lipid peroxidation inhibiting activities (Table 1) [Jose and Janardhanan, 2000]. The extract also showed significant reducing power and radical scavenging property as evident from FRAP assay (Ajith and Janardhanan, 2007) and DPPH radical scavenging assay (Lakshmi et al., 2004; Ajith and Janardhanan, 2007).

Table 1. In vitro antioxidant activity of ethyl acetate (EtOAC), methanol (MeOH) and aqueous (AQ) extracts of $P$. rimosus (Pr), G. lucidum (GI), $P$. florida (Pf), and $P$. pulmonarius (Pp) [Ajith and Janardhanan, 2007].

\begin{tabular}{lcccc}
\hline Extracts & \multicolumn{4}{c}{ IC50 $(\boldsymbol{\mu g} / \mathbf{m l})$} \\
\cline { 2 - 5 } & $\begin{array}{c}\text { Super oxide } \\
\text { scavenging }\end{array}$ & $\begin{array}{c}\text { Nitric oxide } \\
\text { scavenging }\end{array}$ & $\begin{array}{c}\text { Hydroxyl radical } \\
\text { scavenging }\end{array}$ & $\begin{array}{c}\text { Lipid } \\
\text { peroxidation } \\
\text { inhibiting }\end{array}$ \\
\hline EtOAc & $22.0 \pm 1.0(\mathrm{Pr})$ & $438.0 \pm 21.6(\mathrm{Pr})$ & $68.0 \pm 4.1(\mathrm{Pr})$ & $162 \pm 7.0(\mathrm{Pr})$ \\
& $-(\mathrm{Pf})$ & $-(\mathrm{Pf})$ & $530.0 \pm 29.4(\mathrm{Pf})$ & $496.0 \pm 4.7(\mathrm{Pf})$ \\
$\mathrm{MeOH}$ & $25.3 \pm 1.2(\mathrm{Pr})$ & $126.7 \pm 12.6(\mathrm{Pr})$ & $93.0 \pm 10.3(\mathrm{Pr})$ & $282 \pm 12.8(\mathrm{Pr})$ \\
& $152.5 \pm 2.5(\mathrm{Gl})$ & $-(\mathrm{Gl})$ & $560.0 \pm 0.1(\mathrm{Gl})$ & $873.5 \pm 7.2(\mathrm{Gl})$ \\
& $-(\mathrm{Pp})$ & $-(\mathrm{Pp})$ & $476.7 \pm 24.6(\mathrm{Pp})$ & $960.0 \pm 10.0(\mathrm{Pp})$ \\
$\mathrm{AQ}$ & $-(\mathrm{Pf})$ & $-(\mathrm{Pf})$ & $263.3 \pm 24.9(\mathrm{Pf})$ & $320.0 \pm 10.0(\mathrm{Pf})$ \\
& $126.0 \pm 5.1(\mathrm{Pr})$ & $31.0 \pm 4.5(\mathrm{Pr})$ & $71.0 \pm 4.7(\mathrm{Pr})$ & $318 \pm 2.4(\mathrm{Pr})$ \\
& $475.0 \pm 25.0(\mathrm{Gl})$ & $-(\mathrm{Gl})$ & $140.0 \pm 2.0(\mathrm{Gl})$ & $-(\mathrm{Gl})$ \\
& $-(\mathrm{Pf})$ & $-(\mathrm{Pf})$ & $263.3 \pm 24.9(\mathrm{Pf})$ & $-(\mathrm{Pf})$ \\
\hline
\end{tabular}

Values are mean $\pm S D, n=3$. Names of mushrooms included in the parenthesis.

The antioxidant potential of $L$. edodes methanol extract was investigated in the search for new bioactive compounds from natural resources. The measured DPPH radical scavenging activity is depicted by Sasidharan et al. (2010). The free radical scavenging activities were $39.0 \%, 41.0 \%$ and $66.00 \%$ for the $L$. edodes extract, vitamin $E$ and $B H T$, respectively. The EC50 value is $4.4 \mathrm{mg} / \mathrm{mL}(y=11.7 x-1.693, R 2=0.988)$ which is the concentration of the crude extract that decreases the initial DPPH radical concentration by $50 \%$. Effectiveness of antioxidant properties is inversely correlated with EC50 values. Cheung and Cheung (2005) also reported the antioxidant activity of $L$. edodes against lipid peroxidation. They found that the low molecular weight sub-fraction of the water extract of $L$. edodes had the highest antioxidant activity against lipid peroxidation of rat brain homogenate, with IC50 values of $1.05 \mathrm{mg} / \mathrm{mL}$. In addition, other mushrooms have also been reported to possess antioxidant activity. Wong and Chye (2009) reported the antioxidant activity of Pleurotus porrigens, Hygrocybe conica, Xerula furfuracea (Rooted oude), Schizophyllum commune, Polyporus tenuiculus (Pore fungus) and Pleurotus florida. Based on the results they obtained, petroleum ether (PE) and methanolic extracts from these edible wild mushrooms were effective in DPPH radical scavenging and metal chelating ability. PE extracts were more effective than methanolic extracts in antioxidant activity using the $\mathrm{DPPH}$, whereas methanolic extracts were more effective in reducing power and metal chelating ability.

\subsection{Cardiovascular and Hypercholesterolemia Effect of Mushroom}

Diabetes mellitus (DM) is a major endocrine disorder affecting nearly $10 \%$ of population all over the world. The major risk factors in development of coronary artery disease (CAD) have been identified as DM, increased blood levels of total cholesterol, low density lipoprotein 
(LDL) cholesterol and very low density lipoprotein (VLDL) cholesterol as well as lowered levels of high density lipoprotein (HDL) cholesterol. Mushrooms in general and Pleurotus, Lentinus, Grifola in particular, because of their high fibre content, proteins, microelements and low caloric value, are almost ideal for diets designed to prevent cardiovascular diseases as first suggested by traditional Chinese Medicine. The therapeutic potential of Agaricus bisporus and its antioxidant effect in hypercholesterolemia induced albino rats has been studied (Kolandaivel and Gandheeswari, 2009). The consumption of $P$. florida supplemented diet renders anti-hyperglycaemic as well as anti-hypercholesterolemia effect to alloxan induced diabetic rats (Bandopadhyay et al., 2009). Previous studies had shown the antihyperglycaemic effect of aqueous extracts of $P$. pulmonarius against alloxan-induced diabetic mice (Badole and Bodhankar, 2007; Badole and Bodhankar, 2008; Badole et al., 2008). The anti-hyperglycaemic effect of medicinal mushroom may be for its due to its significant antioxidant activities properties (Khatun et al., 2009).

Lentinus edodes can lower both blood pressure and free cholesterol in plasma, as well as accelerate accumulation of lipids in liver by removing from circulation. In most developed countries, the common cause of death is coronary artery disease. The main risk factors are hypercholesteromia and dislipoproteinemia, diabetes, disturbance in blood platelet binding and high blood pressure. The initial step in the prevention and treatment of CAD and hypercholesterolemia is the modification of nutritional regime with a diet low in fats and fatty acids and rich in crude fibres. Clinical intervention studies have clearly demonstrated therapeutic importance of correcting hypercholesteromia (Alberts et al., 1989).

Mevinolin is produced commercially from the filamentous fungus Aspergillus tereus. This is the first specific inhibitor of microzomal enzyme that occurs early in the biosynthetic pathway to cholesterol formation. The addition of $4 \%$ dried Pleurotus to a high cholesterol diet reduced cholesterol accumulation in the serum effectively and liver of experimental rats. Cholesterol lowering effect of the mushroom Pleurotus ostreatus in hypercholesterolemic rats is also reported. It has been suggested Pleurotus mushrooms could be recommended as natural cholesterol lowering substance within the human diet (Gunde-Cimerman, 1999).

In Western countries coronary artery disease is the major cause of death, while hypercholesterolemia is a risk factor, which causes the hardening of the arteries. In humans, $50 \%$ or more of total cholesterol I is derived from de novo synthesis. It has been proven that Shiitake mushroom is used to lower blood serum cholesterol (BSC) via a factor known as eritadenine, which is also called 'Lentinacin' or 'Lyntisine'. It is known that, apparently, eritadenine reduces BSC in mice, not by inhibition of cholesterol biosynthesis, but by the acceleration of excretion of ingested cholesterol and its metabolic decomposition (Suzuki and Oshima, 1974-1976). Eritadenine also lower the blood levels of cholesterol and lipids in animals.

\subsection{Antimicrobial Properties}

In recent years Basidiomycetes and other higher fungi including some recognized medicinal mushrooms have been recognized medicinal mushrooms have been re-investigated as sources of novel antibiotics mainly as a result of increasing difficulty and the cost of isolating novel bioactive compounds from the Actinomycetes and Streptomycetes. The research possess an idea about the antibiotic activity of some of the important wild mushrooms of Central India (Karwa and Rai, 2009). Growth of medically challenged bacteria like S. aureus and $B$. cereus was inhibited by five mushrooms out of six selected. Moreover the synthetic antimicrobial discs have been showed a marked increase in their activity when combined 
with mushroom extract. The petroleum ether, chloroform, acetone and water extracts of mushroom Osmoporus odoratus has been observed that the antibacterial activity against Staphylococcus aureus, Streptococcus pyogenes, Bacillus subtilis, E. coli and Pseudomonas aeruginosa; the water extract alone showed antibacterial activity against the tested organisms and the results were comparable with that of amphicillin rather than chloramphenicol (Sivakumar et al., 2006). Determination of antimicrobial activity profile of Lycoperdon perlatum, Cantharellus cibarius, Clavaria vermiculris, Ramaria formosa, Maramius oreades and $P$. pulmunarius tested against a panel standard pathogenic bacteria and fungi indicated that the concentration of bioactive components directly influence the antimicrobial capability of the isolates (Ramesh and Pattar, 2010). Quershi et al. (2010) have studied that the antimicrobial activity of various solvent extracts $(40 \mu \mathrm{g} / \mathrm{ml})$ of Ganoderma lucidum was tested against six pathogenic species of bacteria. Acetone extract exhibited maximum antibacterial activity (31.60 \pm 0.10$)$, while the most susceptible bacterium observed was Klebsiella pneumoniae. The antimicrobial effect of ethanol extracts of Pleurotus sajorcaju, $P$. florida and P. aureovillosus were tested against four species of Gram-positive bacteria, five species of Gram-negative bacteria and one species of yeast.

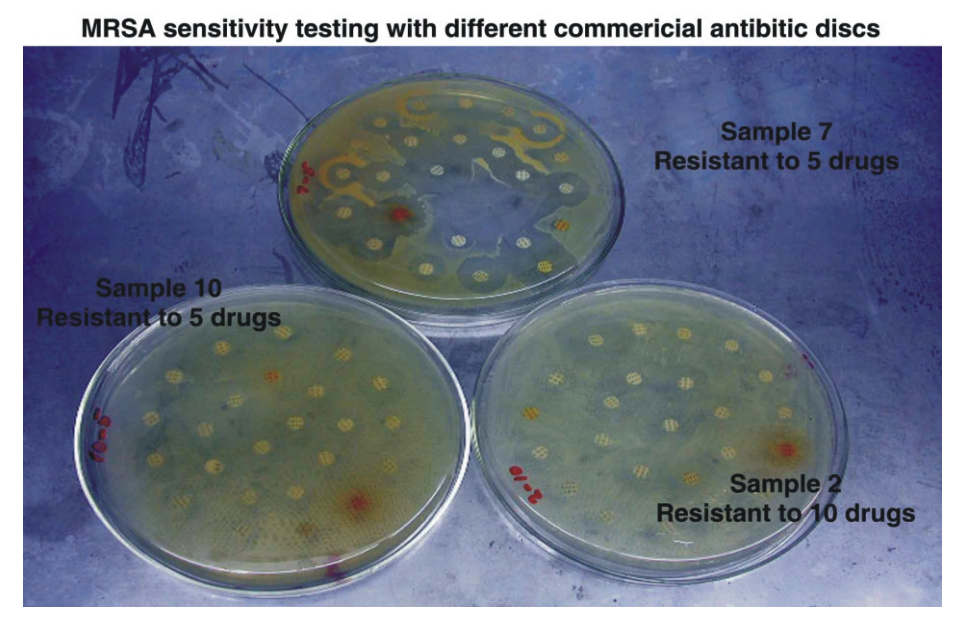

Figure 4. MRSA sensitivity testing with different commercial antibiotic disc (Prasad and Wesely, 2008)

Pleurotus species had a narrow antibacterial spectrum against Gram-negative bacteria and strongly inhibited the growth of the Gram-positive bacteria tested, including Bacillus subtilis, and $M$. luteus (Loganathan et al., 2008). The antioxidant and antiviral activities against Herpes simplex virus 1 (HSV-1) and Human Influenza viruses of the solvent extract is obtained from an edible mushroom Agaricus heterocystis under in vitro condition (Loganathan et al., 2009). Sheena et al., (2003) have observed that three macrofungi Ganoderma lucidum, Navesporus floccose and Phellinus rimosus are showing antibacterial activity that occurring in South India. G. Iucidum, which not only contains 120 different triterpenes but also polysaccharides, proteins and other bioactive compounds, the spectrum of detected the pharmacological activities of mushrooms is very broad on Multidrug (Figure 4-6) resistant Staphylococcus aureus (Prasad and Wesely, 2008). 


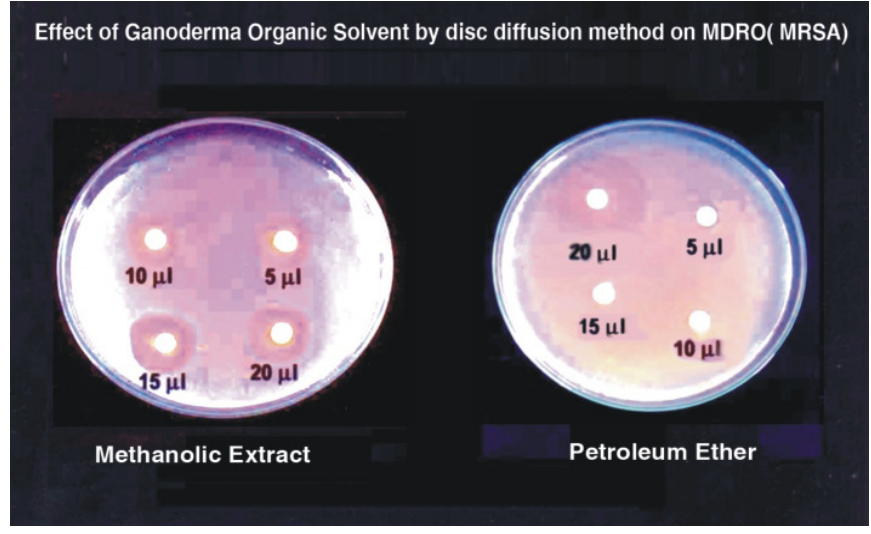

Figure 5. Effect of Ganoderma organic solvent by disc diffusion method on MDRO (MRSA) (Prasad and Wesely, 2008)

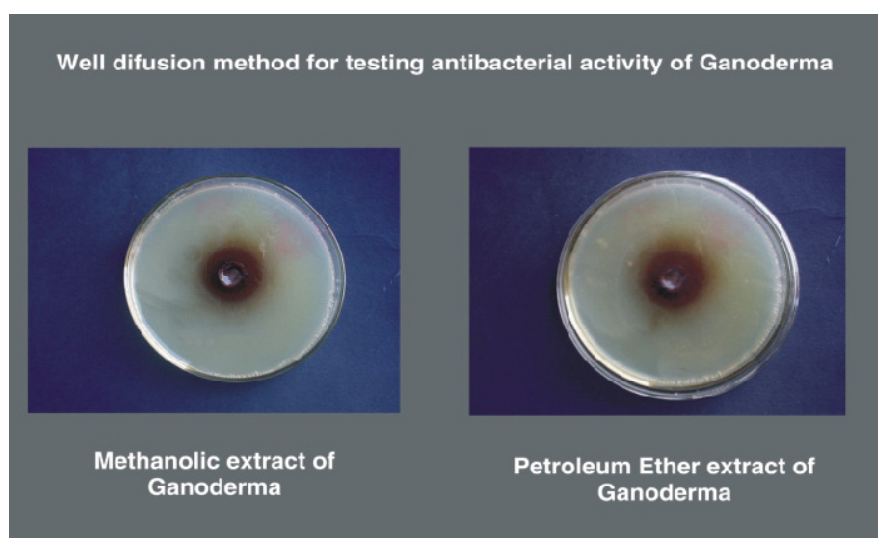

Figure 6. Well diffusion method for testing antibacterial activity of Ganoderma (Prasad and Wesely, 2008)

New sesquiterpenoid hydroquinones, produced by the European Ganoderma species Ganoderma pfeifferi Bres. and named ganomycins, inhibit the growth of methicillin- resistant Staphylococcus aureus and other bacteria (Mothana et al., 2000). Besides, whole extracts of this mushroom inhibit the growth of microorganisms responsible for skin problems (Fan et al., 2006) [Pityrosporum ovale, Staphylococcus epidermidis, Propionibacterium acnes, unpublished results]. Steroids like 5a-ergosta-7, 22-dien-3b-ol (3) or 5,8-epidioxy-5a,8aergosta-6, 22-dien-3b-ol (Smania et al., 2003; Kuznetsov et al., 2005), isolated from Ganoderma applanatum (Pers.) Pat., proved to be weakly active against a number of Grampositive and Gram-negative microorganisms (Kuznetsov et al., 2005). Oxalic acid is an agent responsible for the antimicrobial effect of Lentinula edodes (Berk.) Pegler against $S$. aureus and other bacteria (Badalyan, 2004). Ethanolic mycelial extracts from L. edodes possess antiprotozoal activity against Paramecium caudatum (Badalyan, 2004). The antimicrobial activity of Podaxis pistillaris (L. Pers.) Morse, used in some parts of Yemen for the treatment of nappy rash of babies and in South Africa against sun burn (Ofodile et al., 2005), is caused by epicorazins. These substances belong to the group of epipolythiopiperazine- 2, 5-diones, an important class of biologically active fungal metabolites (Ofodile et al., 2005). Other antimicrobial compounds from the Aphyllophorales were summarized by Zjawiony (2004). 
Many antimicrobial compounds such as terpenes, lectins, polysaccharides etc. act on the bacterial cytoplasmic membrane (Lin and Chou, 1984; Yang et al, 2002). Various extracts of G. lucidum have been found to be equally effective when compared with gentamycin sulphate. Dulger and Gonuz (2004) reported the antimicrobial properties of 4 different extracts of macrofungus (Cantharellus cibarius) against 50 important human pathogens. He observed good antimicrobial activity with ethanol and acetone extracts against most of the pathogens. Cowan (1999) reported that the most active components are generally water insoluble, hence it is expected that low polarity organic solvents would yield more active extracts. In the present study the aqueous extract exhibited least derivative from G. lucidum against $E$. coli and $P$. aeruginosa followed by $S$. aureus. While least zone of inhibition was recorded for Bacillus species. Klaus and Miomir (2007) have studied the influence of various extracts isolated from G. lucidum on E. coli, Bacillus species, S. aureus and Salmonella species. The aqueous fruiting body extract showed maximum zone of inhibition against Bacillus species while least zone of inhibition was reported for E. coli and Salmonella species. Yoon et al. (1994) investigated the bioactivity of aqueous extracts from the fruiting body of $G$. lucidum and found that the extracts also exhibited inhibitory activity towards Bacillus species. Extracts from G. applanatum (Smania et al., 1999) and G. pfeifferi (Mothana et al., 2000) have been shown to possess significant antibacterial activity against E. coli. Sheena et al. (2003) reported that methanol extract of G. lucidum showed remarkable antibacterial activity against $E$. coli, Salmonella species and $B$. subtilis. Keypour et al. (2008) investigated the antibacterial activity of a chloroform extract of G. lucidum from Iran. The results of disc diffusion tests showed that the chloroform extract had growth inhibitory effects on B. subtilis and S. aureus. Smania et al. (2007) observed MIC value of 2 $\mathrm{mg} / \mathrm{ml}$ for $E$. coli and $P$. aeruginosa while $1 \mathrm{mg} / \mathrm{ml}$ in case of $S$. aureus and $0.25 \mathrm{mg} / \mathrm{ml}$ for Bacillus species with $G$. australate extract. Significantly high MIC ofan aqueous Ganoderma extract against $B$. subtilis $(3.5 \mathrm{mg} / \mathrm{ml})$, Bacillus species $(3.5 \mathrm{mg} / \mathrm{ml})$ have been reported by Yoon et al. (1994). Keypour (2008) recorded MIC value of $8 \mathrm{mg} / \mathrm{ml}$ for $S$. aureus and $B$. subtilis with chloroform extract of $G$. lucidum. Results with present mushroom indicate the MIC values to be lower in comparison to MIC value obtained by other investigators, indicating that the acetone extract possesses more potential as an antibacterial agent at lower concentrations.

The water extract of Lentinus edodes demonstrated growth-enhancing effects on colon inhabiting beneficial lactic acid bacteria, Lactobacillus brevis and Bifidobacteria brevis and Bifidobacteria brevie. The effective factor in the extract is considered to be the disaccharide sugar, tehalose. The $L$. edodes extract can improve the beneficial intestinal flora of the gut and reduced harmful effects of certain bacterial such as $\beta$-gucosidase, $\beta$-glucorinidase and tryptophase as well as reducing colon cancer formation (Bae, 1997). It is clear from the results that mushrooms also have antimicrobial properties.

The bioactive compounds like mniopetals, oudemansin, lanostane activity (Table 2). Their does compensation and mode of action is subject for research for new generation researchers. Clearly, the antimicrobial potential of extract of several medicinal mushroom types and indeed other Basidiomycetes not yet exploited must warrant further examination. The heavy molecular weight cell wall polysaccharides, for example, PSP from Trametes versicolor inhibits growth of infection yeast, such as Candida albicans (Tsukagoshi, 1984; Sakagami, 1991-1993). Antitumour polysaccharides inhibit bacteria such as Bacillus subtilis, Staphylococcus aureus, Escherichia coli and Pseudomonas aeruginosa. Hericium erinaceum shows strong antimicrobial activity against a broad range of infectious agents. Compounds extracted from Agaricus bisporus, Lentinus edodes, Coprinus comatus and Oedemansiella mucida have been reported to have antifungal and antibacterial properties. 
Table 2. Compounds showing antimicrobial activity.

\begin{tabular}{|c|c|c|c|}
\hline Mushrooms & Bioactive compounds & Bioactivity & Reference \\
\hline $\begin{array}{l}\text { Cheimonophylum } \\
\text { candissimum }\end{array}$ & Cheimonophyllon A-E & $\begin{array}{l}\text { Antibacterial, } \\
\text { Weak antifungal }\end{array}$ & $\begin{array}{l}\text { Standler et al., } \\
1994\end{array}$ \\
\hline $\begin{array}{l}\text { Clitocybe } \\
\text { cyathiformis }\end{array}$ & Cyathiformine $\mathrm{A}$ & $\begin{array}{l}\text { Antibacteria, } \\
\text { Antifungal }\end{array}$ & $\begin{array}{l}\text { Arnone et al., } \\
1993\end{array}$ \\
\hline Clitocybe diatreta & Diatretol & Antibacterial & $\begin{array}{l}\text { Arnone et al., } \\
1996\end{array}$ \\
\hline $\begin{array}{l}\text { Coprinus } \\
\text { atrementarius }\end{array}$ & Illudin C2, Illudin C3 & Antimicrobial & Lee et al., 1996 \\
\hline $\begin{array}{l}\text { Crepidotus } \\
\text { fulvotomentosus }\end{array}$ & Strobilurin $\mathrm{E}$ & Antifungal & $\begin{array}{l}\text { Weber et al., } \\
1989\end{array}$ \\
\hline Favolaschia sp. & Favolon & Antifungal & $\begin{array}{l}\text { Anke et al., } \\
1995\end{array}$ \\
\hline $\begin{array}{l}\text { Flagelloscypha } \\
\text { pilatii }\end{array}$ & Pilatin & Antibiotic & $\begin{array}{l}\text { Heim et al., } \\
1988\end{array}$ \\
\hline Lentinus edodes & Lentinan & Antiviral & Mizuno, 2000 \\
\hline Mniopetalum sp. & Mniopetals & Antimicrobial & $\begin{array}{l}\text { Kuschel et al., } \\
1994\end{array}$ \\
\hline Mycena sp. & $\begin{array}{l}\text { Strobilurin M, } \\
\text { Tetrachloropyrocatechol }\end{array}$ & $\begin{array}{l}\text { Antifungal, } \\
\text { Antibacterial }\end{array}$ & $\begin{array}{l}\text { Daferner et al., } \\
1998\end{array}$ \\
\hline $\begin{array}{l}\text { Omphalotus } \\
\text { illudens }\end{array}$ & Illudinic acid & Antibacterial & $\begin{array}{l}\text { Dufresne et al., } \\
1997\end{array}$ \\
\hline $\begin{array}{l}\text { Oudemansiella } \\
\text { radicata }\end{array}$ & Oudemansin $\mathrm{X}$ & Antifungal & $\begin{array}{l}\text { Anke et al., } \\
1990\end{array}$ \\
\hline Poria cocos & Lanostane & $\begin{array}{l}\text { Phospholipase A2, } \\
\text { Inhibitor (group of } \\
\text { anti-inflammatory } \\
\text { agents) }\end{array}$ & $\begin{array}{l}\text { Cuellar et at., } \\
1996\end{array}$ \\
\hline
\end{tabular}

\subsection{Hepatoprotective and Antitumor Effect}

Bilirubin concentration has been used to evaluate chemically induced hepatic injury. Besides various normal functions, liver excretes the breakdown product of hemoglobin namely bilirubin into bile. It is well known that necrotizing agents like paracetamol produce sufficient injury to hepatic parenchyma to cause large increases in bilirubin content (Plaa and Hewitt, 1982). Lentinus edodes extract prevented severity of liver damage caused by paracetamol as evidenced by the low level of bilirubin in the serum. Similar results were also reported by Jayakumar et al. (2006). They used oyster mushroom (Pleurotus ostreatus) extracts on $\mathrm{CCl} 4$-induced liver damage in male Wistar rats. They reported that when rats with CCl4induced hepatotoxicity were treated with the extract of $P$. ostreatus, the serum SGOT, SGPT and SALP levels reverted to near normal.

Figure 7 shows (Sasidharan et al., 2010) the liver tissue of mice which received $1 \mathrm{~mL} / \mathrm{kg}$ of saline and free access to pellets. Control group showed a normal liver architecture of hepatocytes where they were well arranged without any alteration at central and portal veins. 


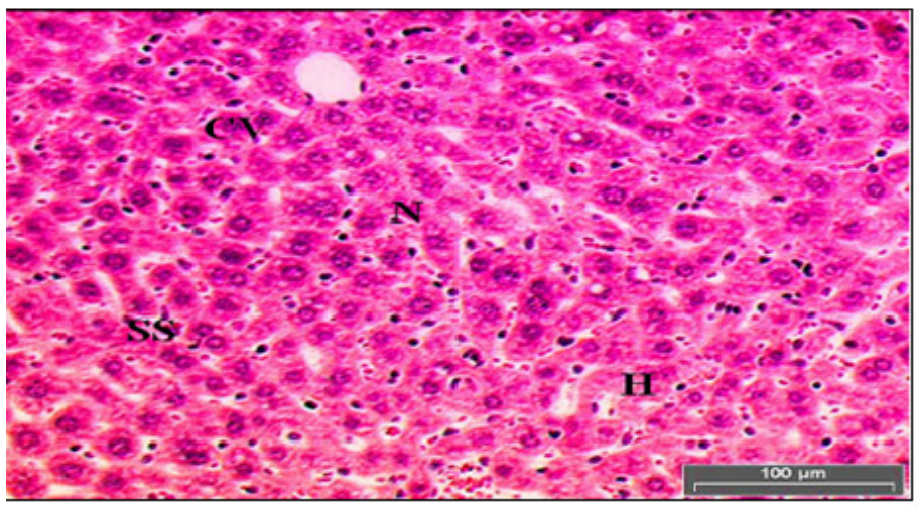

Figure 7. Light microphotographs of haematoxylin and eosin stained sections of the formalin fixed liver cell of normal mice.

Liver cells of Group 1 mice (normal) have hepatic cells with well-preserved cytoplasm, prominent nucleus and nucleolus. ( $H$, hepatocytes; $N$, nucleus; $S S$, sinusoid; $C V$, central vein)

[Sasidharan et al., 2010].

Figure 8 shows mice liver tissue damage induced with paracetamol $(1.0 \mathrm{~g} / \mathrm{kg}$ paracetamol orally $\times 7$ days). Toxic effect such as liver damage, haemolytic anaemia, oxidative damage to the red blood cells and bleeding tendencies due to over dosage of paracetamol was noted.

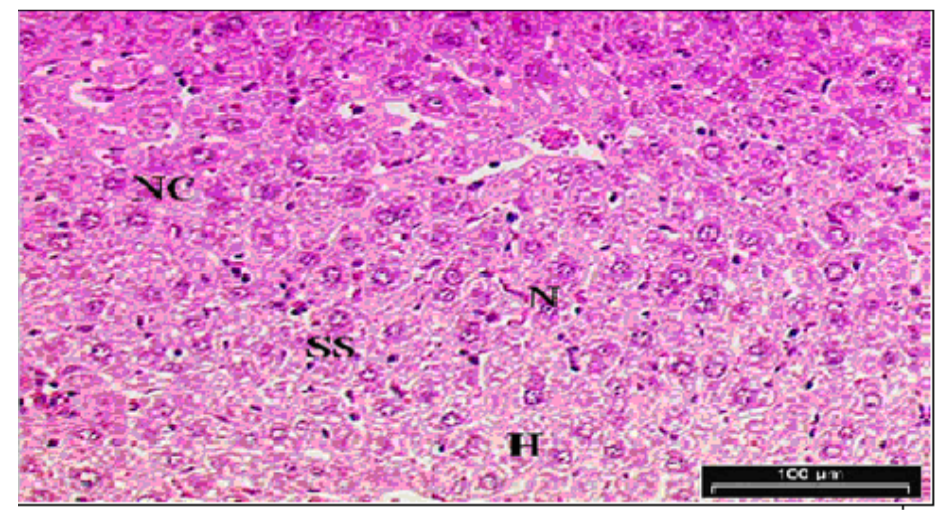

Figure 8. Light microphotographs of haematoxylin and eosin stained sections of the formalin fixed liver cell of mice exposed to paracetamol.

Liver cells of Group II mice (exposed to paracetamol) revealed extensive fatty changes, characterized by the disruption of the lattice nature of the hepatocyte, damaged hepatic sinusoids and necrosis.

Presences of reticular sides are visible and nucleuses of two to three are joined together. $(H$, hepatocytes; N, nucleus; SS, sinusoid; NC, necrosis) [Sasidharan et al., 2010].

Figure 9 shows the mice liver tissue induced with paracetamol and treated with $L$. edodes extract. L. edodes is highly known for its medicinal value as an antioxidant agent that prevents free radicals produced by paracetamol toxicity. In this study, mice were given oral paracetamol $1 \mathrm{~g} / \mathrm{kg}$ to induce hepatotoxicity and this was challenged by $200 \mathrm{mg} / \mathrm{kg}$ of mushroom extract $3 \mathrm{~h}$ after the administration of paracetamol. The treatment was continued for seven days. Only minimal disruption of the structure of hepatocytes was noted in liver tissue of mice exposed to paracetamol and $L$. edodes extract. 


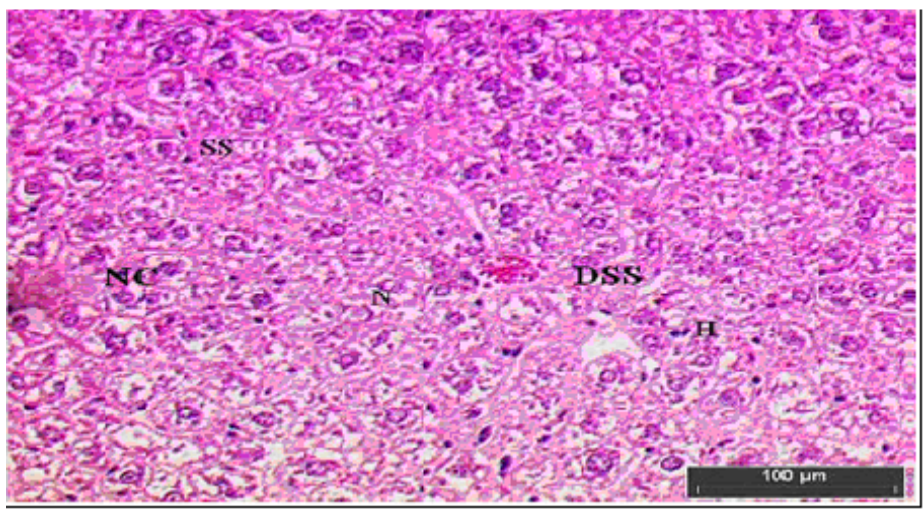

Figure 9. Light microphotographs of haematoxylin and eosin stained sections of the formalin fixed liver cells of mice treated with mushroom extract.

Liver cells of Group III mice (exposed to paracetamol and mushroom extract), only minimal disruption of the hepatic cellular structure was observed. Nucleases are at recovery stages and absence of joined nuclease. Sinusoids are slowly recovering and their presence of dilated sinusoid filled with red blood cells. (H, hepatocytes; N, nucleus; SS, sinusoid; NC, necrosis; DSS, dilated sinusoid filled with red blood cells) [Sasidharan et al., 2010].

The liver tissue of mice treated with Lentinus edodes extract displayed cell recovery compared to the mice induced with paracetamol alone (Figure 9). Hepatocytes were being transformed to normal polyhedral shape with some cell lining observed. Nucleuses are slowly improving and clumping of nucleus is not seen.

Lentinus edodes is a very popular food in Asia and the raw materials can be stably supplied by cultivation of the mycelia, the extract is a promising candidate for use as an antioxidant and hepatoprotective agent (Laksmi et al., 2004; Sasidharan et al., 2010). Another Indian mushroom, Phellinus rimosus shows anti-hepatotoxic activities (Ajith and Janardhanan, 2002). Hepatoprotective activity also has been studied from Trianthema portulacastrum $L$. against paracetamol and thioacetamide intoxication in albino rats (Kumar et al., 2004). Scientists have discovered that the polysaccharide compound lentinan, found in shitake mushrooms, possess immunostimulant and anti tumour properties. Lentinan can also prevent platelet adhesion, which causes the clots responsible for coronary artery disease and stroke. All the three extracts like Ethyl acetate, methanol and aqueous extracts of the $P$. rimosus when tested for antitumour activity were found to inhibit the Dalton's Lymphoma Ascites (DLA) cell line induced solid tumor in mice and Ehrlich's Ascites Carcinoma (EAC) cell line induced ascites tumor in mice (Ajith and Janardhanan, 2003). Medicinal mushrooms occurring in India namely Ganoderma lucidum, Phellinus rimosus, Pleurotus florida and Pleurotus pulmonarius possessed profound antioxidant and antitumour activities (Jose et al., 2002, Ajith and Janardhanan, 2007). Laganathan et al. (2009) have studied that the anticancer property of Agaricus bisporus. Research shows that reishi mushroom (Baskar et al., 2008; Jones and Janardhanan, 2000) combat tumours inhibit the body's production of cholesterol and stimulates the immune benefits.

Polysaccharides or peptideglycan, pharmaceutically active mushroom compounds, continue to be the subject of most researches, including isolation, chemical structures and experiments in vitro or in vivo. Ten years ago the researches were concentrated on the four mushrooms, Lentinus (Lentinula) edodes, Schizophyllum commune, Grifola frondosa, and Sclerotinia sclerotiorum, particularly their respective b-glucans, lentinan, schizophyllan (also 
called SPG, sonifilan, or sizofiran), grifolan, and SSG. Most of them, b-(1-6)-branched b-(13)-linked glucans, were found to exhibit significant antitumor activity (Borchers et al., 2004). In recent years, little additional research has been conducted with these four mushrooms, but a host of other species has been investigated and a variety of species has been explored (Lindequist et al., 2005; Ohno et al., 2001). At least 651 species representing 182 genera of hetero- and homobasidiomycetes mushrooms contain antitumor or immunostimulating polysaccharides (Ohno et al., 2000; Ajith and Janardhanan, 2003; Jose et al., 2002; Bezivin et al., 2003; Fan et al., 2006). There are also several reports of mushrooms containing more than one polysaccharide with antitumor activity (Borchers et al., 1999). An interesting example is $A$. blazei. It contains an antitumor glucan with a b-1, 6 backbone (Itoh et al., 1994; Mizuno, 1999), which differs from the b-1, 3 backbone with b-1, 6 branches shared by many other antitumor glucans. In addition, a glucomannan with the main chain of b-1, 2linked D-mannopyranosyl residues has been isolated from this mushroom and found to inhibit tumorigenesis (Mizuno et al., 1999). The lipid fraction of $A$. blazei was found to contain a compound with antitumor activity, subsequently identified as ergosterol (Takaku et al., 2001). The lipid fraction of Grifola frondosa exhibited antioxidant activity and inhibited the cyclooxygenase enzymes, COX-1 and COX-2 (Inoue et al., 2002; Takaku et al., 2001; Smania et al., 1999). Ergosterol was again identified as one of the most active constituents.

Oxidative damage is strongly implicated in the development of many chronic diseases, including cancer. The inducible form of COX, COX-2, also appears to play an important role in certain cancers. Its inhibition can result in the inhibition of tumor development, and it appears to be beneficial even in some established tumors (Bender et al., 2003). Other mushroom constituents may inhibit promotion or progression by exerting direct cytotoxicity against tumor cells (Chang, 1996), interfering with tumor angiogenesis, or upregulating other nonimmune tumor-suppressive mechanisms.

\subsection{Clinical Trials and Availability of Medicine in India}

The National Cancer Institute ( $\mathrm{NCl}$ ), United States has recently intensified its emphasis upon natural products such as plants, marine organisms and selected class of microorganisms as sources for new drug discovery. Screening of plant extracts for anticancer activity began at $\mathrm{NCl}$ in 1956. Many of the currently available and clinically useful anticancer drugs are either natural plant products or derivatives of natural products e.g. paclitaxel (Taxol) from Taxus brevifolia and vincristin (Oncovin) from Catharanthus roseus (Peuzuto, 1997). Plants continue to offer a wide range of compounds with diverse structure and activities in modern cancer therapy.

Ikekawa et al. (1969) published one of the first scientific reports on antitumor activity of extracts of mushrooms against implanted Sarcoma 180 in animals. Soon after, three major anticancer drugs, Krestin from cultured mycelium of Trametes (Coriolus versicolor), Lentinan from fruiting bodies of Lentinus edodus and Scizophyllan from Schizophyllum commune, were developed (Wasser and Weis, 1999; Mizuno, 1999; Ikekawa, 2001). While much attention has been drawn to various immunological and anticancer properties of these mushrooms they offer other potentially important therapeutic properties including antioxidant, antihypertensive, antidiabetic, anti-inflammatory, hepatoprotective etc. Several mushroom derived compounds are now increasingly used in Japan, Korea and China as adjuvant to standard radio- and chemotherapy. The most encouraging effect is the ability of these mushroom derived compounds when administered prior to or during radio- or chemotherapy significantly reduced the side effects from these treatments. Reactive oxygen and nitrogen species are implicated in the pathophysiology of several diseases. Oxidative damage to 
DNA may initiate carcinogenesis. Most mushrooms derived preparations and substances find their use not as a pharmaceutical but as a novel class of dietary supplement (DS) or nutraceuticals that fall very well into the concept of functional food. Dietary chemotherapeutic agents may serve as potent agents for enhancing therapeutic effect of chemotherapy, radiotherapy and offer standard therapies for the treatment of human cancer (Sarkar and $\mathrm{Li}$, 2006). Mushrooms derived compounds have been shown to possess potent antitumor activities in both pre-clinical models and clinical trials. The safety criteria of these compounds have been exhaustively studied with little evidence of toxicity.

Ganoderma lucidum and related species have the longest historical usage for medicinal properties dating back at least four thousand years (Zhao and Zhang, 1994). In Japan it is called Reishi and in China and Korea it is variously called Ling Chu and Ling Zhi (Mushroom of immortality). Traditionally it has been used widely in the treatment of hepatopathy, chronic hepatitis, nephritis, hypertension, arthritis, insomnia, bronchitis, asthma and gastric ulcer.

Scientific studies have confirmed that the substances extracted from the mushrooms can reduce blood pressure, blood cholesterol and blood sugar level as well as inhibition of platelet aggregation. Ganoderma species are famous tonic in Chinese medicines. They are widely distributed in India on tree trunks. Ganoderma belongs to the polyporaceae family of Basidiomycota. Generally Ganoderma species are described as beneficial to all viscera and non-toxic (Liu, 1999). For 4000 years G. lucidum has beenused as a part of Chinese and Japanese medicine especially for the treatment of most of the human ailments including chronic hepatitis, nephritis, hepatopathy, neurasthenia, arthritis, bronchitis, asthma, gastric ulcer etc.

G. Iucidum (Rai, 2006) and other mushrooms like G. applanatum, L. edodes, Flamulina velutipes, Grifola frondosa from China, Korea, Japan and India have been used in many clinical studies with animals and humans, reporting the beneficial results (Rai et al., 2005). There are several companies marketing their produce in India. These companies import the medicine into India in tablet/thecapsule form and sell it as a high value medicine for cure of chronic/terminal diseases like cancers/AIDS. G. lucidum capsules are available in packs of 100 capsules, alone and in combination with other medicinal mushrooms like caterpillar mushroom, shitake and other mushroom. The companies marketing these are: Fungi Perfecti, USA; Mycology Research Laboratory, UK; Nammex (North American Medicinal Mushroom Extra), USA; Core nutritional Products, USA and others (Dhar and Sharma, 2009). Cordyceps sinensis medicine is available in freeze-dried mycelia form in capsules, alone and in combination with freeze-dried caterpillar mushroom. These medicines are available as "over the counter" products in Indian in all big cities. Its consumption is conspicuous in areas in north (Delhi-Chandigarh) and Southern India, in the state of Kerala. The consumption is high due to more per capita income of the people in these areas. Moreover, the consumption is confined to well-to-do families only (Dhar and Sharma, 2009).

Clinical trials were conducted on 56 cancer patients, 30 were chosen to receive the medicinal mushroom extract mix and another 26 comparable patients receiving the accepted pharmaceutical drug Polyactin-A as a control group. All patients were in the middle-late stages (Stage 3 and 4 ) of cancer. The experiment concludes that the tablets of mixed polysaccharides, made up of the six species of medicinal mushrooms, can become a new health product to improve immunity with high effectiveness and nontoxicity. However, further trials are needed. 
The polysaccharides extracted from Agaricus brasiliensis, Grifola frondosa, Lentinus edodes, Ganoderma lucidum, Trametes versicolor and Cordyceps sinensis are used to produce tablets for inhibiting the growth of tumours and improving the immunity. The products of Ganoderma lucidum are prescribed in various forms, it can be injected as a solution of powdered spores or given as syrup. It can be taken as tea, soup, capsules, tinctures, or bolus. In tincture form, the dose given is $10 \mathrm{ml}$ thrice daily. In case of syrup the dose is 4-6 ml/day. The dried mushroom $(200-300 \mathrm{~g})$ is prepared in water and given as a drink, the recommended dose is 3-5 times daily (Ying et al., 1987; Zhuang et al., 1993).

In Japan, Ganoderma lucidum is used for the treatment of the cancer (Willard, 1990). The results obtained after application shows that the patient sleeps well with a healthier feeling and has an increased appetite; Reishi also provides relief from angina pectoris. Injection of spore powder is effective in curing progressive deterioration, atrophy and muscles stiffness. The effect of elevation changes has been prevented and cured by tablets of mushroom spores.

In a experimental study for therapeutic application of G. lucidum, 143 patients with advanced previously treated cancer were given an oral G. lucidum polysaccharide extract of $1800 \mathrm{mg}$ three times daily for 12 weeks. Twenty seven patients were not assessable for responsible and toxicity, because they were unable to track for follow-up or refused further therapy before the 12 weeks of treatment were up. Of the 100 fully assessable patients, $46(32.2 \%)$ had progressive disease before or at the six weeks evaluation point (range: 5 days-6 weeks). There was no significant change in the Functional Assessment of Cancer TherapyGeneral (FACT-G) scores in 85 assessable patients. In the group with stable disease, FACT-G scores improved in 23 patients, remained unchanged in five, and declined in one. Within this group, the median change from the baseline score to the 6 and 12 weeks was +7.6 and +10.3 , both statistically significant $(P<0.05)$. For the 38 patients with $S D$, the median change from the baseline score was $28.1 \pm 10.2$ weeks. This indicates that Ganopoly may have an adjunct role in the treatment of patients with advanced cancer although objective responses were not observed in the study (Wasser and Weis, 1997a).

G. Iucidum and other mushrooms like G. applanatum, Lentinus edodes, Flammulina velutipes, Grifola frondosa from China, Korea, Japan and India have been used in many clinical studies with animals and humans, reporting the beneficial results. The high molecular-weight polysaccharides from the cell wall of G. lucidum are physiologically active. They are used against various diseases like diabetes, Alzheimer's disease, retinal pigmentary degeneration, atrophic myotonous hepatodymia, rhinitis, leucopoenia, insomnia, dyspnea, neurasthemia and duodenal ulcers. The water extract from fruit body had inhibitory activity on histamine release from rat peritoneal mast cells, induced by compounds $48 / 80$ or antigen-antibody reaction and on passive cutaneous anaphylaxis reaction in guinea pigs and the rats. The activity is due to the Ganoderic acid C and D, which are also responsible for the treatment of asthma and allergy. The polysaccharides and triterpenoids have also shown the anti-HIV activity. They also show protective effects on liver in animal and human studies (Wasser and Weis, $1997 \mathrm{~b}$ ).

Ganopoly is well-tolerated and appears to be active against HBV patients with chronic hepatitis-B. The mechanism for hepatoprotective effects of G. lucidum has been largely undefined. However, accumulating evidence suggests several possible mechanisms, which include antioxidants and radical scavenging activity, modulation of hepatic Phase I and II enzymes inhibition of $\beta$-glucuronidase, antifibrotic and antiviral activity, modulation of NO production, maintenance of hepatocellular calcium homeostasis and immunomodulating 
effects. G. lucidum also cures lung and heart dysfunction. Clinical studies on this were conducted in China in which 200 patients with chronic bronchitis were given G. Iucidum in tablet form and $60-90 \%$ patients showed marked improvement with increased appetite. It also reduced blood and plasma viscosity in hypertensive patients with hyperlipidaemia. The extracts of this mushroom were reported to reduce blood cholesterol and blood pressure and also treat arrhythmia (Ding, 1987; Cheng et al., 1993). G. lucidum has also shows hypoglycaemic and hypolipidemic activities. In a study, 71 patients with confirmed type II diabetes mellitus were cured and had best results. This study demonstrated that Ganopoly is efficacious and safe in lowering blood glucose concentration.

\section{Table 3. Current biomedical applications of Ganoderma lucidum}

\begin{tabular}{|c|c|c|}
\hline \multicolumn{2}{|c|}{ Applications } & References \\
\hline \multirow[t]{5}{*}{ A. } & Immunomodulating effects & Chang, 1994 \\
\hline & 1. Anticancer & Mizuno, 1995a, 1995b, 1995c \\
\hline & 2. Antiviral (e.g., anti-HIV) & Kim et al., 1994 \\
\hline & 3. Antibacterial & Yoon et al., 1994 \\
\hline & 4. Therapy of auto-immuno disorders & Chang, 1993, 1994, 1996 \\
\hline \multirow[t]{3}{*}{ B. } & Cardiovascular disorders & \\
\hline & $\begin{array}{l}\text { 1. Coronary dilation and increasing } \\
\text { coronary circulation }\end{array}$ & Soo, 1994,1996 \\
\hline & $\begin{array}{l}\text { 2. Anti-hyperlipidemic, and antiplatelet } \\
\text { hypoglycaemic aggregation (blood } \\
\text { clots) }\end{array}$ & Chang and But, 1986 \\
\hline \multirow[t]{5}{*}{ C. } & Cancer therapy & \\
\hline & 1. Maintain leucocyte count & Chang, 1994; Soo, 1994 \\
\hline & 2. Enhance the immune system & Soo, 1996 \\
\hline & $\begin{array}{l}\text { 3. Reduction of chemotherapy toxicity and } \\
\text { elimination of induced leucopenia (low } \\
\text { blood leucocytes) by chemotherapy }\end{array}$ & $\begin{array}{l}\text { Chang and But, 1986; Hu and But, } \\
\text { 1987; Chen and Yu, 1993; Mizuno, } \\
\text { 1995a, 1995b, 1995c. }\end{array}$ \\
\hline & 4. Remission to prevent relapses & Chang, 1994 \\
\hline D. & $\begin{array}{l}\text { Remission of cancer and hepatitis B } \\
\text { treatment }\end{array}$ & $\begin{array}{l}\text { Ventura and Messerl, 1987; Chang, } \\
\text { 1993; Mizuno, 1995a, 1995b, } \\
\text { 1995c. }\end{array}$ \\
\hline \multirow[t]{2}{*}{ E. } & $\begin{array}{l}\text { Enhancing oxygen utilization } \\
\text { 1. Relief of discomfort of high altitude } \\
\text { stress, headaches dizziness, nausea } \\
\text { and insomnia }\end{array}$ & Dharmananda, 1988 \\
\hline & $\begin{array}{l}\text { 2. Relief of oxygen deprivation caused by } \\
\text { coronary arteries blocked by } \\
\text { atheromas, spasms or colts }\end{array}$ & Mizuno, $1995 \mathrm{c}$ \\
\hline \multirow{6}{*}{$\begin{array}{l}\text { F. } \\
\text { G. } \\
\text { H. }\end{array}$} & $\begin{array}{l}\text { Anti-ageing, anti-oxidant free radical } \\
\text { scavengers }\end{array}$ & Mizuno, 1995a, 1995b, 1995c. \\
\hline & Antidiabetic & Gunde-Cimerman, 1999 \\
\hline & $\begin{array}{l}\text { Other examples usage in combination with } \\
\text { other medicine }\end{array}$ & \\
\hline & 1. Physical exercise & Alexeev and Kupin, 1993 \\
\hline & 2. Improving work capacity & Mizuno, 1995a, 1995b, 1995c. \\
\hline & 3. Rapid recovery of normal physiology & Mizuno, 1995a, 1995b, 1995c. \\
\hline
\end{tabular}

Ref: Willard, 1990; Chen and Yu, 1993; Wasser, 2005a, 2005b; Rai et al., 2005. 
The practitioner experiences along with preliminary clinical reports indicate that immunostimulating polysaccharides, inducing HIV and Epstein Barr Virus (EBV), the cause of mononucleosis. The G. lucidum is one of the ingredients in skin lotions produced for protection against UV radiation (Ying et al., 1987). Current biomedical applications of $G$. lucidum are given in Table 3.

\section{CONCLUSION}

The China has a long tradition of 5000 years for using Mushroom as Medicines and as consumable edibles. The China is the first among the countries for production, research and marketing of mushroom. Regarding production and technologies for production of medicines from mushroom, China has a cutting edge than other countries and India is far behind in respect of this ground. Diabetes is a major endocrine disorder causing morbidity and mortality worldwide. The problem of diabetes is particularly relevant to India, as several studies have clearly documented an increased ethnic susceptibility to diabetes in-migrant Asian Indians (Ramaiya et al., 1991). Recent epidemiological studies have pointed to the growing epidemic of diabetes in India (Mohan et al., 2006). Indeed, according to the recent Diabetes Atlas produced by the International Diabetes Federation (IDF), India is home to the largest number of people with diabetes in the world, 40.9 million diabetic subjects in 2007, and these numbers are predicted to increase to 69.9 million by 2025 (Mohan et al., 2008). In country like India most of the people live below the subsistence level or poverty line and suffer from protein deficiency or protein hungriness. To combat this situation extensive research and cultivation of edible mushrooms in our country is imperative. Considering India's potentials for mushroom cultivation, its conducive ecological diversities, biodiversities, climatic and geographical diversities, and vast man power which are congenial, lead India as a major player in global scenario of mushroom production. The mushroom industry is gradually taking route in India but the pace is rather slow because of insufficient scientific support and inadequate training programmes (Kapoor, 2004). The Indian mushroom Industry needs very badly modern technology for their survival in competitive International market. The research reports summarized in this article have highlighted the Indian mushroom cultivation as well as medicinal importance as nutraceuticals, anti-oxidative, cardiovascular, hypercholesterolemia, antimicrobial, hepatoprotective, anticancer, clinical trials and availability of mushroom medicines in India. However, the screening of mushrooms from different ecological and geographical regions of India is still required to identify, isolate, design, develop, modify or to prepare new pharmacologically active compounds from wild mushrooms. The mechanism of action of various secondary metabolites isolated from medicinal and wild edible mushroom is yet to be elucidated. Government Organizations spread over our country have already taken extensive initiative to aware the common people to practice mushroom cultivation as well as research. Non Government Organizations too, are actively taking initiative in this respect but enough scope is still lacking to disseminate the knowledge to each and every one of a vast country like ours.

\section{ACKNOWLEDGEMENT}

First author Selima Khatun acknowledges the UGC Meritorious Fellowship, Govt. of India, for providing fellowship and financial assistance. 


\section{COMPETING INTERESTS}

Authors have declared that no competing interests exist.

\section{REFERENCES}

Agahar-Murugkar, D., Subbulakshmi, G. (2005). Nutritional value of edible wild mushrooms collected from the Khasi hills of Meghalaya. Food Chem, 89, 599-603.

Ahmad, N., Mukhtar, H. (1999). Green tea polyphenols and cancer. Biological mechanisms and practical implications. Nutr. Rev., 57(3), 78-83.

Ajith, T.A., Janardhanan, K.K. (2001). Antioxidant and anti-inflammatory activities of methanol extract of Phellinus rimosus. Ind. J. Exp. Biol., 39, 1166-1169.

Ajith, T.A., Janardhanan, K.K. (2002). Antioxidant and antihepatotoxic activities of Phellinus rimosus (Berk) Pilat. J.Ethnopharmacol., 81: 387-391.

Ajith, T.A., Janardhanan, K.K. (2003). Cytotoxic and antitumor activities of a polypore macrofungus Phellinus rimosus (Berk) Pilat, J. Ethnopharmacol. 84, 157-162.

Ajith, T.A., Janardhanan, K.K. (2007). Indian Medicinal Mushrooms as a Source of Antioxidant and Antitumor Agents. J. Clin. Biochem. Nutr., 40, 157-162.

Alberts, A.W., MacDonald J.S., Till, A.E., Tobert, J.A. (1989). Lovastatin. Cardiovac. Drug Rev., 7, 89-109.

Alexeev, V, Kupin, V. (1993). Ganoderma lucidum administration in air spacemadicine. $5^{\text {th }}$ International Symposium on Ganoderma lucidum. Seoul, pp. 60-63.

Anke, T., Werle, A., Bross, M., Steglich, W. (1990). Antibiotics from basidiomycetes XXXIII, Oudemansin $\mathrm{X}$, a new antifungal $\mathrm{E}$ - $\beta$-Methoxyacrylate from Oudemansiella radiate (Rehlan ex Fr) Sing., J. Abtibiot. (Tokyo), 43(8), 1010-1011.

Anke, T., Werle, A., Zapf, S., Velten, R., Steglich, W. (1995). Favolon, a new antifungal triterpenoid from a Favolaschia species. J. Antibiot. (Tokyo), 48, 725-726.

Arnone, A., Capelli, S., Nasini, G., Meille, S.V., De Pava, O.V. (1996). Secondary mould metabolites II structure elucidation of diatretol - a new diketopiperzine metabolite from the fungus Clitocybe diatreata. Liebigs Ann. 11, 1875-1871.

Arnone, A., Cardillo, R., Nasini, G., Pava, O.V.D. (1993). Cyathiformines A-D, new chorismate derived metabolites from the fungus Clitocybe cyathiformis. Tetrahedron, 49, 7251-7258.

Arya, C., Arya, A. (2003). Effect of acid hydrolysis of substrate on yield of oyster mushroom Pleurotus sajor-caju (Fr.) Singer. Mushroom Res. 12, 35-38.

Atri, N.S., Saini, S.S., Kaur, G. (1995). Taxonomic studies on the North Indian Agarics: The genus Termitomyces Heim. Mush. Res. 4, 7-10.

Badalyan, S.M. (2004). Antiprotozoal activity and mitogenic effect of mycelium of culinarymedicinal shiitake mushroom Lentinus edodes (Berk.) Singer (Agaricomycetidae), Int. J. Med. Mushrooms, 6, 131-138.

Badole, S.L., Bodhankar, S.L. (2008). Effect of concomitant administration of aqueous extract of Pleurotus pulmonarius and metformin in diabetic mice. J. Compl. Integ. Med., 5(1), 27.

Badole, S.L., Patel, N.M., Thakurdesai, P.A., Bodhankar, S.L. (2008). Interaction of aqueous extract of Pleurotus pulmonarius (Fr.) Quel-Champ. with Glyburide in alloxan induced diabetic mice. Evidence-Based Compl. Alt. Med., 5 (2), 159-164.

Bae, E.A., Kim, D.H., Han, M.J. (1997). Effect of Lentinus edodes on the growth of intestinal lactic acid bacteria. Arch. Pharm. Res., 20, 443-447. 
Bandopadhyay, S., Chatterjee, N.C. (2009). Water hyacinth, a low-cost supplement for oyster mushroom (Pleurotus florida) cultivation. Mushroom. Res. 18(1), 5-9.

Bandopadhyay, S., Khatun, S., Mitra, S., Roy, P., Dasgupta, A., Chaudhuri, S.K., Chattopadhyay, N.C. (2009). Antihyperglycaemic effect of dietary mushroom (Pleurotus florida) in alloxan induced diabetic rats. Proc. $5^{\text {th }}$ Int. Medicinal Mushroom Conference, Mycological Society of China, Nantong, China. pp.135-141.

Baskar, R., Lavanya, R., Mayilvizhi, S., Rajasekaran, P. (2008). Free radical scavenging activity of antitumour polysaccharide fractions isolated from Ganoderma lucidum (Fr.) P. Karst. Natur. Prodc. Rad., 7(4), 320-325.

Bender, S., Dumitrache, C.N., Backhaus, J., Christie, G., Cross, R.F., Lonergan, G.T. (2003). A case for caution in assessing the antibiotic activity of extracts of culinarymedicinal Shiitake mushroom [Lentinus edodes (Berk.) Singer] (Agaricomycetidae). Int. J. Med. Mushrooms, 5, 31-35.

Bezivin C., Delcros, J.G., Fortin, H., Amoros, M., Boustie, J. (2003). Toxicity and antitumor activity of a crude extract from Lepista inversa (Scop. Fr.) Pat. (Agaricomycetideae): A preliminary study. Int. J. Med. Mushrooms. 5, 25-30.

Bhawani, D., Nair, N.C. (1987). Aditions to Indian agaricales. Indian Mush. Sci., 2, 371-374.

Bisaria, R., Madan, M., Bisaria, V.S. (1987). Mineral content of the mushroom P. sajor-caju cultivated on different agroresidues. Mush. J. Tropics. 7, 53-60.

Boa, E. (2004). Wild Edible Fungi, A Global Overview of Their Use and Importance to People. Non-wood Forest Products Series no. 17. FAO, Rome, p. 147.

Borchers, A.T., Keen, C.L., Gershwin, M.E. (2004). Mushrooms, tumors, and immunity: An update, Exp. Biol. Med., 229, 393-406.

Borchers, A.T., Stern, J.S., Hackman, R.M., Keen, C.L., Gershwin, M.E. (1999). Mushrooms, tumors and immunity. Proc. Soc. Exp. Biol. Med. 221, 281-293.

Chang, R. (1993). Limitations and potential applications of Ganoderma and related fungal polyglycans in clinical ontology; 1st International Conf. on Mushroom Biol. and Mushroom products, p. 96.

Chang, R. (1994). Effective dose of Ganoderma in humans, in: Buhanan, P.K., Hseu, R.S., Moncalvo, J.M. (Eds.), Proceedings Contributed Symposium 59 A, B. $5^{\text {th }}$ Int. Mycol. Congr., Taipei, pp. 101-113.

Chang, R. (1996). Fuctional properties of edible mushrooms. Nutr. Rev., 54(11), 91-93.

Chang, S.T. (1996). Mushroom research and development - Equality and mutual benefit, Proceedings of the 2nd International Conference on Mushroom Biology and Mushroom Products, Pennsylvania State University, Pennsylvania, USA, pp. 1-10.

Chang, S.T. (1999). Global impact edible and medicinal mushrooms on human welfare in the $21^{\text {st }}$ century: Non green evolution. Int. J. Med. Mushr., 1, 1-7.

Chang, H.M, But, P.P.H. (Eds.), (1986). Lingzhi, in: Pharmacology and application of Chinese materia medica, World Scientific Publishing, Singapore, pp. 642-653.

Chatterjee, R., Srinivasan, K.S. and Maiti, P.C. (1957). Cordyceps sinensis: Structure cordycepic acid. J. Am. Pharm. Assoc., 46, 114-118.

Cheng, H.H., Hou, W.C, Lu, M.L. (1993). Interactions of lipid metabolism and intestinal physiology with Tramella faciformis Berk. Edibile mushroom in rats fed a high cholesterol diet with or without Nebacitin. J. Agric. Food Chem., 50 (25), 7438-7443.

Cheng, K.F., Leung, P.C. (2008). General review of polysaccharopeptides (PSP) from $C$. versicolor: Pharmacological and clinical studies. Cancer Therapy, 6, 117-130.

Chen, R.Y., Yu, D.Q. (1993). Studies on the triterpenoid constituents of the spores from Ganoderma lucidum, Yao Hsueh Hsueh Pao (Acta Pharm. Sinica), 26, 267-273.

Cheung, L.M., Cheung, P.C.K. (2005). Mushroom extracts with antioxidant activity against lipid oxidation. Food Chem., 89, 403-409. 
Cowan, M.M. (1999). Plant products as antimicrobial agents. Clinical Microbiol. Rev., 12(4), 564-582.

Cuellar, M.J., Giner, R.M., Recio, M.C., Just, M.J., Manez, S., Rios, J.L. (1996). Two fungal lanostane derivative as phospholipase A2 inhibitors. J. Nat. Prod., 59, 977-979.

Daferner, M., Anke, T., Helwig, V., Steglich, W., Sterner, O., Strobilurin, M. (1998). Tetrachloropyrocatechol and Tetrachloropyrocatechol methyl ether: New antibiotics from Mycena species. J. Antibiot. (Tokyo), 51, 816-822.

Das, N., Mahapatra, S.C., Chattopadhyay, R.N. (2000). Use of wild grasses as substrate for cultivation of oyster mushroom in South West Bengal. Mushroom Res., 9, 95-99.

Dhar, B.L., Sharma, S.K. (2009). Medical Mushroom product in India, present status and future trading. Proc. $5^{\text {th }}$ Int. Medicinal Mushroom Conference, Mycological Society of China, Nantong, China, pp. 403-406.

Dharmananda, S. (1998). Medicinal Mushrooms. Best Ways Magazine, July, pp. 54-58.

Ding, G. (1987). Antiarrhythmia agents in traditional medicines. Abstr. Chin. Med., 1, 287308.

Doshi, A., Sharma, S.S. (1997). Wild Mushroom of Rajasthan, in: Advances in Mushroom Biology and Production. Proc. Indian Mushroom Conference, MSI, NCMRT, Solan pp. 105-127.

Dufresne, C., Young, K., Pelacz, F., Val, A.G.D., Valentino, D., Graham, A., Platas, G., Brenard, A., Zink, D. (1997). Illudinic acid, a novel illudane sesquiterpine antibiotic. J. Nat. Prod. 60, 188-190.

Dulger, B., Gonuz, A. (2004). Antimicrobial activity of certain plants used in Turkish traditional medicine. Asian Journal of Plant Sci., 3, 104-107.

Fan, I., Pan, H., Soccol, A.T., Pandey, A., Soccol, C.R. (2006). Advances in mushroom research in last decade. Food Technol. Biotechnol., 44(3) 303-311

Guerrero, D.G., Martinez, V.E., Almaraz, R.D.L.T. (2011). Cultivation of Trametes versicolor in Mexico. Micologia Aplicada Inter., 23(2), 55-58.

Gunde-Cimmerman, N. (1999). Medicinal value of the genus Pleurotus (Fr.) P. Kaest. (Agaricales S.I., Basidiomycetes). Int. J. Med. Mushrooms, 1, 69-80.

Gunde-Cimmerman, N., Freidrich, J., Cimmerman, A., Benicki, N. (1993). Screening fungi for the production of an inhibitor of HMG CoA reductase, production of mevinolin by the fungi of the genus Pleurotus. FEMS Microbiol. Lett., 111, 203-206.

Heim, J., Anke, T., Mocek, U., Steffan, B., Steglich, W. (1988). Antibiotics from Basidiomycetes XXIX: Pilatin, A new antibiotically active marasmane derivative from cultures of Flagelloscypha pilatii Agerer. J. Antibiot. (Tokyo), 41, 1752-1757.

Hu, B., But, P. (1987). Chinese material medica for radiation protection. Abstr. Chin. Med., 1, 475-490.

Ikekawa, T. (2001). Beneficial effects of mushrooms, edible and medicinal, a health care. Int. J. Med. Mushr., 3, 79-82.

Ikekawa, T., Uehara, N., Maeda, Y., Nakanishi, M., Fukuoka, F. (1969). Antitumor activity of aqueous extracts of edible mushrooms. Cancer Res., 29, 734-735.

Inoue, A., Kodama, N., Nanba, H. (2002). Effect of maitake (Grifola frondosa) D-fraction on the control of the T Lymph node Th-1/Th-2 proportion, Biol. Pharm. Bull., 25, 536-540.

Itoh, H., Ito, H., Amano, H., Noda, H. (1994). Inhibitory action of a $(1,6)$-beta-D-glucanprotein complex (F III-2-b) isolated from Agaricus blazei Murill. (Himematsutake) on Meth A fibrosarcoma- bearing mice and its antitumor mechanism. Jpn. J. Pharmacol., 66, 265-271.

Jandaik, C.L. (1974). Artificial cultivation of the mushroom Pleurotus sajor-caju (Fr.) Singer. Mushroom J., 22, 405. 
Jandaik, C.L. (1997). History and development of Pleurotus cultivation in the world and future perspective, in: Rai, R.D., Dhar, B.L., Verma, R.N. (Eds.), Advances in Mushroom Biology and Production, India: MSI Solan, pp. 181-192.

Jandaik, C.L., Kapoor, J.N. (1974). Studies on cultivation of Pleurotus sajor-caju. Mush. Sci., 9(1), 667-672.

Jayakumar, T., Ramesh, E., Geraldine, P. (2006). Antioxidant activity of the oyster mushroom, Pleurotus ostreatus, on CCl4-induced liver injury in rats. Food Chem. Toxicol., 44, 1989-1996.

Jones, S., Janardhanan, K.K. (2000). Antioxidant and antitumor activity of Ganoderma lucidum (Cart. Fr.) P.Karst.-Reishi (Aphyllophoromycetidae) from South India. Int. J. Med. Mushroom, 2, 195-200.

Jose, N., Ajith, T.A., Janardhanan, K.K. (2002). Antioxidant, anti-inflammatory and antitumor activities of culinary medicinal mushroom Pleurotus pulmonarius (Fr.) Quel. (Agaricomycetideae). Int. J. Med. Mushr., 4, 329-335.

Jose, N., Janardhanan, K.K. (2000). Antioxidant and antitumor activity of Pleurotus florida. Curr. Sci., 79, 941-943.

Kannaiyan, S., Ramaswamy, K. (1980). A hand book of edible mushrooms. Today and Tomorrows pub., New Delhi, pp. 39-43.

Kapoor, J.N. (2004). Mushroom cultivation. Indian Council of Agricultural Research, Pusa, New Delhi, p. 83.

Karwa, A., Rai, M. (2009). Mycoenhancing the potential of synthetic antibiotics using wild mushrooms: First report. Proc. $5^{\text {th }}$ Int. Medicinal Mushroom Conference, Mycological Society of China, Nantong, China. pp. 167-172.

Keypour, S., Riahi, H., Moradali, M.F., Rafati, H. (2008). Investigation of the antibacterial activity of a chloroform extract of Ling Zhi or Reishi Medicinal Mushroom, Ganoderma lucidum (W. Curt. Fr) P. Karst. (Aphyllophoromycetideae) from Iran. Int. J. Med. Mushrooms, 10(4), 345-349.

Khatun, S., Bandopadhyay, S., Mitra, S., Roy, P., Chaudhuri, S.K., Dasgupta, A., Chattopadhyay, N.C. (2009). Nutraceutical and antioxidative properties of three species of Pleurotus mushrooms. Proc. $5^{\text {th }}$ Int. Medicinal Mushroom Conference, Mycological Society of China, Nantong, China. pp. 234-241.

Kim, B.K, Kim, H.W., Choi, E.C. (1994). Anti-HIV effects of Ganoderma lucidum, in: Ganoderma: Systematics, Phytopathology and Pharmacology: Proceedings of Contributed Symposium 59 A, B. $5^{\text {th }}$ Int. Mycol. Congr. Vancouver.

Klaus, A., Miomir, N. (2007). Influence of the extracts isolated from Ganoderma lucidum mushroom on some microorganisms. Proceedings of Nat. Sci., Matica Srpska Novi Sad., 113, 219-226.

Kolandaivel, P.G., Gandheeswari, P. (2009). Therapeutic potential of Agaricus bisporus and its antioxidant effect in hypercholesterolemic induced Albino rats. Proc. $5^{\text {th }}$ Int. Medicinal Mushroom Conference, Mycological Society of China, Nantong, China. pp. 519-525.

Kumar, G., Banu, G.S. Pappa, P.V., Sundararajan, M., Pandian, M.R. (2004). Hepatoprotective activity of Trianthema portulacastrum L. against paracetamol and thioacetamide intoxication in albino rats. J. Ethnopharmacol., 92, 37-40.

Kushchel, A., Anke, T., Velten, R., Klostermeyer, D., Steglich, W., Konig, B. (1994). The Mniopetals, new inhibitors of reverse transcriptases from a Mniopatalum species (Basidiomycetes), J. Antibiot. (Tokyo), 47, 733-739.

Kuznetsov, O.I., Milkova, E.V., Sosnina, A.E., Sotnikova, N.I. (2005). Antimicrobial action of Lentinus edodes juice on human microflora. Mikrobiol. Epidemiol. Immunobiol., 1, 8082. 
Laganathan, K.J., Gunasundari, D., Hemalatha, M., Shenbhagaraman, R., Kaviyarasan, V. (2010). Antioxidant and phytochemical potential of wild edible mushroom Termitomyces reticulatus: Individual cap and stipe collected from South Eastern Part of India. Int. J. Pharm. Sci., 1(7), 62-72.

Laganathan, K.J., Ramalingam, S., Venkatasubbu, V., Venketesan, K. (2008). Studies on the phytochemical, antioxidant and antimicrobial properties of three indigenous Pleurotus species. Journal of Molecular Biology \& Biotechnology, 1, 20-29.

Lakhanpal, T.N. (1995). Mushroom flora of North West Himalaya, in: Chandha, K.L., Sharma, S.R. (Eds.), Advances in Horticulture Vol.13-Mushroom. Malhotra Pub. House, New Delhi, pp. 351-373.

Lakhanpal, T.N., Rana, M. (2005). Medicinal and nutraceutical genetic resources of mushrooms. Plant Genetic Resources: Characterization and Utilization. 3, 288-303.

Lakshmi, B., Ajith, T.A., Sheena, M., Nidhi, G., Janardhanan, K.K. (2003). Antiperoxidative, anti-inflammatory and antimutagenic activities of ethanol extract of the mycelium of Ganoderma lucidum occurring in South India. Teratogen. Carcinogen. Mutagen., 22, 1-13.

Lakshmi, B., Tilak, J.C., Adhikari, S., Devasagayam, T.P.A., Janardhanan, K.K. (2004). Evaluation of antioxidant activity of selected Indian mushrooms. Pharmaceutical Biol., 42, 179-185.

Lee, I.K, Jeong, C.Y., Cho, S.M., Yun, B.S., Kim, Y.S., Yu, S.H., Koshino, H., Yoo, I.D. (1996). Illudin C2 and C3, new illudin C derivatives from Coprinus atramentarius AST20013. J. Antibiot. (Tokyo), 49, 821-822.

Leelavathy, K.M., Ganesh, P.N. (2000). Polypores in Kerala. Daya Publishing House, Delhi, India, pp. 50-60.

Lin, J.Y., Chou, T.B. (1984). Isolation and Characterization of a lectin from edible mushroom, Volvariella volvacea. J. Biological Chem., 96(1), 35-40.

Lindequist, U., Niedermeyer, T.H.J., Julich, W.D. (2005). The pharmacological potential of mushrooms, eCAM, 2, 285-299.

Liu, G.T. (1999). Recent advances in research of pharmacology and clinical application of Ganoderma (P. Karst) species (Aphyllophoromycetideae) in China. Int. J. Med. Mushr. 1, 63-67.

Loganathan, K.J., Kaviyarasan, V., Gopalswamy, S., Sherief, A.K. (2009). Antioxidant and antiviral properties of Agaricus heterocystis Heinem. and Gooss. Proc. $5^{\text {th }}$ Int. Medicinal Mushroom Conference, Mycological Society of China, Nantong, China. pp.173-82.

Madan, M. (1994). Mushroom cultivation for rural development. In: Souvenir National Symposium on Mushrooms, Solan, H.P. pp. 82-87.

Manjula, B. (1983). A revised list of the agaricoid and boletoid basidiomycetes from India and Nepal. Proc. Indian Acad. Sci., 92(2), 81-213.

Medda, R.N. (2001). Studies on nutritional requirements for the cultivation of edible mushrooms and the associated yield. Ph.D. Thesis., Department of Botany, Burdwan University, West Bengal, India. p. 6.

Mizuno, M., Minato, K., Ito, H., Kawade, M., Terai, H., Tsuchida, H. (1999). Antitumor polysaccharide from the mycelium of liquid-cultured Agaricus blazei. Biochem. Mol. Biol. Int., 47, 707-714.

Mizuno, T. (1995a). Shiitake, Lentinus edodes: Functional properties for medicinal and food purposes. Food Rev. Int., 11(1), 111-128.

Mizuno, T. (1995b). Bioactive biomolecules of mushrooms: Food function and medicinal effect of mushroom fungi. Food Rev. Int., 11(1), 7-21.

Mizuno, T. (1995c). Kawariharatake, Agaricus blazei Murrill: Medicinal and dietary effects. Food Rev. Int. 11(1), 167-172. 
Mizuno, T. (2000). Development of an antitumor biological response modifier from Phellinus linteus (Berk. et. Curt) Teng (Aphillophoromycetideae) (review). Int. J. Med. Mushr., 2, 21-33.

Mizuno, T. (1999). The extraction and development of antitumoractive polysaccharides from medicinal mushrooms in Japan (review). Int. J. Med. Mushr., 1, 9-30.

Mohan, V., Deepa, M., Deepa, R., Shanthirani, C.S., Farooq, S., Ganesan, A., Datta, M. (2006). Secular trends in the prevalence of diabetes and impaired glucose tolerance in urban South India-the Chennai Urban Rural Epidemiology Study (CURES-17). Diabetologia, 49, 1175-1178.

Mohan, V., Mathur, P., Deepa, R., Deepa, M., Shukla, D.K., Menon, G.R., Anand, K., Desai, N.G., Joshi, P.P., Mahanta, J., Thankappan, K.R., Shah, B. (2008). Urban rural differences in prevalence of self-reported diabetes in India - The WHO-ICMR Indian NCD risk factor surveillance. Diabetes Res. Clin. Pract., 80, 159-168.

Mothana, R.A.A., Jansen, R., Julich, W.D., Lindequist, U. (2000). Ganomycin A and B, new antimicrobial farnesyl hydroquinones from the basidiomycete Ganoderma pfifferi. Journal of Natural Products, 63(3), 416-418.

Mukherjee, R., Nandi, B. (2002). Role of nutrient supplementation on productivity of Pleurotus spp. on two lignocellulosic biomass and dry matter digestibility of the spent substrate, in: Samajpati, N. (Ed.), Tropical Mycology. Proc. of Third Nat. Symposium, Indian Mycol. Soc. Kolkata. pp. 180-188.

Nageswaran, M., Gopalakrishan, M., Ganesan, M., Vedhamurthy, A., Selaganapadhyay, E. (2003). Evaluation of water hyacinth for culture of oyster mushroom. J. Aqua. Plant Manag., 41, 122-123.

Natrajan, K. (1995). Mushroom flora of South India except Kerala, in: Chandha K.L., Sharma, S.R. (Eds), Advances in Horticulture vol.13-Mushroom. Malhotra Pub. House, New Delhi, pp. 387-397.

Nethravathi, G.P., Sathisha, U.V., Shylaja, M.D., Shashirekha, M.N.U., Rajarathnam, S. 2006. Antioxidant activity of indigenous edible mushrooms. J. Agric. Food Chem., 54(26), 9764-9772.

Nitha, B., Strayo, D., Adhikari, S.K., Devasagayam, T.P.A., Janardhanan, K.K. (2010). Evaluation of free radical scavenging activity of morel mushroom, Morchella esculenta mycelia: A potential source of therapeutically useful antioxidants. Pharmaceut. Biol., 48(4), 453-460.

Ofodile, L.N., Uma, N.U., Kokubun, T., Grayer, R.J., Ogundipe, O.T., Simmonds, M.S. (2005). Antimicrobial activity of some Ganoderma species. Phytother. Res., 19, 310313.

Ohno, N., Furukawa, M., Miura, N., Adachi, Y., Motoi, M., Yadomae, T. (2001). Antitumor bglucan from the cultured fruit body of Agaricus blazei. Biol. Pharm. Bull., 24, 820-828.

Ohno N., Miura, N., Nakajima, M., Yadomae, T. (2000). Antitumor 1, 3-b-glucan from cultured fruit body of Sparassis crispa. Biol. Pharm. Bull., 23, 866-872.

Pardeshi, B.M., Pardeshi, P.M. (2009). The edible medicinal mushrooms as supportive natural nutrients: Study of nonvolatile mineral contents of some edible medicinal mushrooms from India; eastern remedies for modern western maladies. Proc. $5^{\text {th }}$ Int. Medicinal Mushroom Conference, Mycological Society of China, Nantong, China. pp. 514-18.

Perumal, K. (2009). Indigenous technology on organic cultivation of Reishi (Ganoderma lucidum) in India. Proc. $5^{\text {th }}$ Int. Medicinal Mushroom Conference, Mycological Society of China, Nantong, China. pp. 592-595.

Peuzuto, J.M. (1997). Plant derived anticancer agents. Biochem. Pharmacol., 57, 121-133. 
Plaa, G.L., Hewitt, W.R. (1982). Detection and evaluation of chemical induced liver injury, in: Hayes, A.W. (Ed.), Principles and Methods of Toxicology. Raven Press, New York, USA, p. 407.

Prasad, Y., Wesely, W.E.G. (2008). Antibacterial activity of the bio-multidrug (Ganoderma lucidum) on Multidrug resistant Staphylococcus aureus (MRSA). Advanced Biotech., March-No:10, pp. 9-16.

Quereshi, S., Pandey, A.K., Sandhu, S.S. (2010). Evaluation of antibacterial activity of different Ganoderma lucidum extracts. People's J. Scientific Res., 3(1), 9-14.

Rahi, D.K., Shukla, K.K., Rajak, R.C., Pandey, A.K. (2004). Mushrooms and their sustainable utilization. Everyman's Sci., 38(6), 357-365.

Rai, M., Tidke, G., Wasser, S.P. (2005). Therapeutic potential of mushrooms. Natur. Prodc. Rad., 4(4), 246-257.

Rai, R.D. (2006). Biological Diversity; Pharmacological properties, bioactive constituents and clinical studies on the medicinal mushroom, Reishi (G. lucidum). NRCM bulletin, Solan, India. pp.1-28.

Ramaiya, K.L., Kodali, V.R., Alberti, K.G. (1991). Epidemiology of diabetes in Asians of the Indian sub-continent. Int. J. Diabetes Dev. Countr., 2, 15-36.

Ramberg, J.E., Nelson, E.D., Sinnott, R.A. (2010). Immunomodulatory dietary polysaccharides: A systematic review of the literature. Nutrition J., 9, 1-22.

Ramesh, C., Pattar, M.G. (2010). Antimicrobial properties,antioxidant activity and bioactive compounds from six wild edible mushrooms of western ghats of Karnataka, India. Pharmcog. Res., 2(2), 107-112.

Saini, S.S., Atri, N.S. (1983). North Indian Agaricales-VI. Indian J. Mycol. PI. Pathol., 23(3), 250-254.

Sakagami, H., Aoki, T. (1991). Induction of immune potentiation activity by a protein-bound polysaccharide, PSK (Review). Anticancer Res., 11, 993-1000.

Sakagami, H., Takeda, M. (1993). Diverse biological activity of PSK (Krestine), a protein bound polysaccharide from Coriolus versicolor, in: Chang, S.T., Buswell, J.A., Chiu, S.W. (Eds.), Mushroom Biology and Mushroom Products. Chinese University Press, Hong Kong, pp. 237-245.

Sarkar, F.H., Li, Y. (2006). Using chemoprevention agents to enhance the efficacy of cancer therapy. Cancer Res., 66, 3347-3350.

Sasidharan, S., Aravindran, S., Lachimanan, Y.L., Ratnasamy, V., Saravanan, D., Santhanam, A. (2010). In vitro antioxidant activity and hepatoprotective effects of Lentinula edodes against paracetamol-induced hepatotoxicity. Molecules., 15, 44784489.

Sasidharan, S., Darah, I., Jain, N.M.K.M. (2007). Free radical scavenging activity and total phenolic compounds of Gracilaria changii. Int. J. Nat. Eng. Sci., 1, 115-117.

Sharma, J.R. (1995). Ecology and distribution of Hymenochaetaceae, in: Sharma, J.R. (Ed.) Hymenochaetaceae of India, Botanical Survey of India, Calcutta, India, pp. 9-10.

Sheena, N., Ajith, A., Mathew, T.A., Janardhanan, K.K. (2003). Antibacterial activity of three Macrofungi Ganoderma lucidum, Navesporus floccose and Phellinus rimosus occuring in South India. Pharmaceutical Biology 41, 564-567.

Sheena, N., Ajith, T.A., Mathew, A., Janardhanan, K.K. (2006). Antibacterial activity of three macrofungi,

Singh, R.P., Mishra, K.K., Singh, M. (2006). Biodiversity and utilization of medicinal mushrooms. J. Mycol. PI. Pathol., 3, 446-448.

Singh, R.P., Pachauri, V., Verma, R.C., Mishra, K.K. (2008). Catepillar fungus (Cordyceps sinensis). A review. J. Eco-Friendly Agric., 3(1), 1-15. 
Singh, R.P., Rupesh, K.A., Pachauri, V. (2009). Cordyceps sinensis: Their collection, Characterization and Medicinal Components. Proc. $5^{\text {th }}$ Int. Medicinal Mushroom Conference, Nantong, China. pp. 661-669.

Singh, R.P., Verma, R.C., Arora, R.K., Mishra, K.K., Bhanu, C., Singh, M. (2007). Medicinal mushrooms of Uttaranchal with reference to Ganoderma, Auricularia and Cordyceps sinensis, in: Rai, R.D., Singh, S.K., Yadav, M.C., Tewari R.P. (Eds.), Mushroom Biology and Biotechnology. Mushroom Society of India, NRCM Chambaghat, Solan. pp.321-324.

Sivakumar, R., Vetrichelvan, T., Rajendran, N.N., Devi, M.I., Sundaramoorthi, K., Shankar, A.S.K., Shanmugam, S. (2006). Antibacterial activity of mushroom Osmoporus odoratus. 68(4), 523-524.

Sivaprakasm, K., Bhaskaran, T.L., Kandaswamy, T.K. (1979). Mushroom industry and its potential in Tamil Nadu. Farm. Sci., 4, 21-27.

Smania, E.F.A., Monache, D.F. Smania, J.A. Cuneo, Y.R.A. (2003). Antifungal activity of sterols and triterpenes isolated from Ganoderma annulare. Fitoterapia, 74, 375-377.

Smania, E.F.A., Delle, M.F., Yunes, R.A., Paulert, R., Smania, A. (2007). Antimicrobial activity of methyl australate from Ganoderma australe. Brazilian J. Pharmacog., 17(1), 14-16.

Smania, J.A., Monache, D.F., Smania, E.F.A., Cuneo, R.S. (1999). Antibacterial activity of steroidal compounds isolated from Ganoderma applanatum (Pers.) Pat. (Aphyllophoromycetideae) fruit body. Int. J. Med. Mushrooms, 1, 325-330.

Soo, T.S. (1996). Effective dosage of the extract of Ganoderma lucidum in the treatment of various ailments, in: Royse, D.J. (Ed), Mushroom Biology and Mushroom Products. Proceedings of the 2. International Congress, pp. 177-186.

Soo, T.S. (1994). The therapeutic value of Ganoderma lucidum. $8^{\text {th }}$ Int. Mycol. Congr. (IMC5), Abstracts, Vancouver B.C., pp. 95.

Stadler, M., Anke, H., Stener, O. (1994). New nematicidal and antimicrobial compounds from the basidiomycete Cheimonophyllum candidissimum (Berk and Curt) Sing. J. Antibiot. (Tokyo), 47, 1284-1289.

Sudha, A., Lakshmanan, P., Kalaiselvan, B. (2008). Antioxidant properties of paddy straw mushroom (Volvariella volvacea) (Bull. ex Fr.) Sing.) Int. J. Applied Agric. Res., 3(1), 9-16.

Suzuki, S., Oshima, S. (1974). Influence of Shiitake, Lentinus edodes, on human serum cholesterol. Ann. Rep. Nat. Inst. Nutr. 25, 89-94.

Suzuki, S., Oshima, S. (1976). Influence of Shiitake. Lentinus edodes, on human serum cholesterol. Mushr.Sci., 19(1), 463-467.

Takaku, T., Kimura, Y., Okuda, H. (2001). Isolation of an antitumor compound from Agaricus blazei Murill and its mechanism of action. J. Nutr. 131, 1409-1413.

Thakur, M.P., Godara, D.R., Shukla, C.S., Sharma, R.L. (2003). Recent advances in the production technology of Paddy straw Mushroom Biology and Production (ed. R.C. Upadhyay, S.K. Singh, R.D. Rai). MSI, 194-209.

Thilagavathy, D., Kumuthakavally, R., Sanmugam, S. (1991). Study of oyster mushroom cultivation on various substrates, Indian Mushrooms. Proc. National Symposium on Mushroom, Thiruananthapuram. pp. 86-88.

Tiwari, M., Shukla, K., Shukla, R.V., Tripathi, A.M. (2009). Prevalence of tribal mushrooms in Sal forests of Chhattisgarh. J. Mycopathol. Res., 47(2), 111-117.

Tsukagoshi, S. (1984). Krestin (PSK). Cancer Treatment Rev. 11, 131-155.

Ventura, H.O., Messerli, F.H. (1987). Angiotensine converting enzyme inhibitors: A new class of hypertensive drugs, in: Drayer et al. (Eds.) Drugs therapy in hypertension. Marcel Deccer, Inc., pp. 139-161. 
Verma, R.N., Singh, G.B., Singh, S.M. (1995). Mushroom Flora of North Eastern Hills, in: Chandha, K.L., Sharma, S.R. (Eds.), Advances in Horticulture, vol.13, Mushroom. Malhotra Pub. House, New Delhi, pp. 329-349.

Wasser, S.P., Weis, A.L. (1997a). Shiitake mushroom [Lentinus edodes (Berk.) Sing.], in: Nevo, E. (Ed.), Medicinal Mushrooms. Peledfus Press., Haifa, Israel.

Wasser, S.P., Weis, A.L. (1997b). Reishi Mushroom [Ganoderma lucidum (Curt. Fr.) P. Karst.]. in: Nevo, E. (Ed.), Medicinal Mushrooms. Peledfus Press., Haifa, Israel.

Wasser, S.P., Weis, A.L. (1999). Medicinal properties of substances occurring in higher Basidiomycetes mushroom: Current perspective (review). Int. J. Med. Mushr., 1, 3162.

Wasser, S.P. (2005a). Reishi or Ling Zhi (Ganoderma luciderma), in: Enclopedia of Dietary supplements. Marcel Dekker, N.Y. (USA), pp. 603-620.

Wasser, S.P. (2005b). Shiitake (Lentinus edodes), in: Enclopedia of Dietary supplements. Marcel Dekker, N.Y. (USA), pp. 653-664.

Wasser, S.P. (2002). Medicinal mushrooms as source of antitumor and immunomodulating polysaccharides. Appl. Microbiol. Biotechnol., 60, 258-274.

Weber, W., Anke, T., Steffan, B., Steglich, W. (1989). Antibiotics from Basidiomycetes XXXII strobilurin E: A new cytostatic and antifungal (E)-Methoxyacrylate antibiotic from Crepidotus fulvotomentosus Peck. J Antibiot. (Tokyo), 43, 207-212.

Willard, T. (1990). Reishi Mushroom: Herb of spiritual potency and medical wonder. Sylvan Press, Wasington, pp. 110.

Wong, J.Y., Chye, F.Y. (2009). Antioxidant properties of selected tropical wild edible mushrooms. J. Food Compos. Anal., 22, 269-277.

Yang, B.K., Kim, D.H., Jeong, S.C., Das, S., Choi, Y.S., Shin, J.S., Song, S.C., Song, C.H. (2002). Hypoglycemic effect of a Lentinus edodes exo-polymer produced from a submerged mycelial culture. Biosci. Biotechnol. Biochem., 66(5), 937-942.

Ying, J.Z., Mao, X.L., Ma, Q.M., Zong, Y.C., Wen, H.A. (1987). Icons of medicinal fungi from China (Transl. Xu, Y.H.), in: Ying, J.Z., Mao, X.L., Ma, Q.M., Zong, Y.C., Wen, H.A. (Eds.), Illustrations of Chinese Medicinal Fungi. Science Press, Beijing, pp. 579-585.

Yoon, S.Y., Eo, S.K., Kim, Y.S., Lee, C.K., Han, S.S. (1994). Antimicrobial activity of Ganoderma lucidum extract alone and in combination with some antibiotics. Arch. Pharm. Res., 17(6), 438-442.

Zhao, J.D., Zhang, X.Q. (1994). Resources and taxonomy of Ling Zhi (Ganoderma) in China. Int. Symp.Gganoderma Res., Bejing Medical University, Beijing.

Zhuang, C., Mizuno, T., Shimada, A., Ito, H., Suzuki, C., Mayuzumi, Y., Okamota, H., Ma, Y., $\mathrm{Li}$, J. (1993). Antitumor protein-containing polysaccharides from a Chinese mushroom Fengweigu or Houbatake, Pleurotus sajor-caju (Fr.) Sing. Biosci. Biotectnol. Biochem., 57, 901-906.

Zjawiony, J. (2004). Biologically active compounds from Aphyllophorales (Polypore) fungi. J. Nat. Prod., 67, 300-310.

(C) 2012 Khatun et al.; This is an Open Access article distributed under the terms of the Creative Commons Attribution License (http://creativecommons.org/licenses/by/3.0), which permits unrestricted use, distribution, and reproduction in any medium, provided the original work is properly cited. 